\title{
Synthesis Route, Microstructural Evolution, and Mechanical Property Relationship of High-Entropy Alloys (HEAs): A Review
}

\author{
Omoyemi Temitope Onawale *(1), Prince Valentine Cobbinah (1), Rivel Armil Nzeukou (1) \\ and Wallace Rwisayi Matizamhuka
}

check for

updates

Citation: Onawale, O.T.; Cobbinah, P.V.; Nzeukou, R.A.; Matizamhuka, W.R. Synthesis Route, Microstructural Evolution, and Mechanical Property Relationship of High-Entropy Alloys (HEAs): A Review. Materials 2021, 14, 3065. https://doi.org/10.3390/ ma14113065

Academic Editors: Jeong Min Park and Jongun Moon

Received: 16 March 2021

Accepted: 25 May 2021

Published: 4 June 2021

Publisher's Note: MDPI stays neutral with regard to jurisdictional claims in published maps and institutional affiliations.

Copyright: (c) 2021 by the authors. Licensee MDPI, Basel, Switzerland. This article is an open access article distributed under the terms and conditions of the Creative Commons Attribution (CC BY) license (https:/ / creativecommons.org/licenses/by/ $4.0 /)$.
Department of Metallurgical Engineering, Vaal University of Technology, Andries Potgieter Boulevard, Vanderbijlpark 1911, South Africa; prinzcobbs@gmail.com (P.V.C.); rivelnzeukou@yahoo.fr (R.A.N.); wallace@vut.ac.za (W.R.M.)

* Correspondence: onawaleyemi@gmail.com; Tel.: +27-16-950-6748

\begin{abstract}
Microstructural phase evolution during melting and casting depends on the rate of cooling, the collective mobility of constituent elements, and binary constituent pairs. Parameters used in mechanical alloying and spark plasma sintering, the initial structure of binary alloy pairs, are some of the factors that influence phase evolution in powder-metallurgy-produced HEAs. Factors such as powder flowability, laser power, powder thickness and shape, scan spacing, and volumetric energy density (VED) all play important roles in determining the resulting microstructure in additive manufacturing technology. Large lattice distortion could hinder dislocation motion in HEAs, and this could influence the microstructure, especially at high temperatures, leading to improved mechanical properties in some HEAs. Mechanical properties of some HEAs can be influenced through solid solution hardening, precipitation hardening, grain boundary strengthening, and dislocation hardening. Despite the HEA system showing reliable potential engineering properties if commercialized, there is a need to examine the effects that processing routes have on the microstructure in relation to mechanical properties. This review discusses these effects as well as other factors involved.
\end{abstract}

Keywords: high-entropy alloy; powder metallurgy; melting and casting; microstructural evolution; additive manufacturing; solid solution strengthening

\section{Introduction}

The discovery and application of alloying and composite technology have made possible the achievement of various categories of materials that exhibit a wide range of properties. An example is a novel alloy system known as high-entropy alloys (HEAs). Yeh, et al. [1] defined HEAs, by composition, as alloys having at least five principal elements, wherein each has a concentration between 5 and 35 at.\%. In line with Yeh et al.'s research and definition, Miracle et al. [2] also categorized HEAs based on elemental composition and configurational entropy.

Some categories of the HEAs studied are lanthanide HEAs [3,4], refractory HEAs (RHEAs) [5], platinum group metal HEAs (PGM-HEAs) [6], and lightweight HEAs (LWHEAs) [7]. Lanthanide HEAs consist of lanthanide (4f) elements, such as Gd, Lu, Tb, Dy, and Tm [4]. Nb, Ta, W, Mo, V, and Hf usually make up RHEAs [8]. RHEAs are primarily developed for exceptionally high-temperature applications (up to $1400{ }^{\circ} \mathrm{C}$ ), but with a disadvantage of high density. PGM-HEAs consist of precious elements ( $\mathrm{Au}, \mathrm{Ag}, \mathrm{Pt}$, $\mathrm{Ir}$, Os, and Re), while LWHEAs are composed of low-density elements such as $\mathrm{Li}, \mathrm{Mg}, \mathrm{Be}$, and Al.

Over the past decade, material scientists have used several techniques in synthesizing HEAs, such as the melting and casting route, the powder metallurgy (PM) route, and additive manufacturing (AM) processing techniques. The melting and casting route is 
the most common and relatively cheaper fabrication route. However, the high tendency of a heterogeneous structure with elemental segregation and defects accompanies the melting and casting route [9]. The PM process involving mechanical alloying (MA) and consolidation by spark plasma sintering (SPS) is usually used in attempts of achieving homogeneous microstructures in HEAs. The MA and SPS processes are quick, material efficient, and energy efficient. Nonetheless, contamination from the grinding media poses a challenge for the PM synthesis of HEAs [10]. In contrast, the AM fabrication route in recent years has received more attention in circumventing the flaws of other synthesis processes. The AM process is a flexible manufacturing technique with the capability of producing parts with complex geometries, finer microstructures, mass customization, and efficient material usage [11].

Four core effects influence the microstructural evolution of HEA systems. They are the high-entropy effect, sluggish diffusion effect, lattice distortion effect, and cocktail effect. The high-entropy effect indicates that both configurational entropy and enthalpy play significant roles in the solid solution formation of HEAs. Furthermore, the formation of an intermetallic and solid solution chiefly depends on the entropy of mixing $\left(\Delta \mathrm{S}_{\text {mix }}\right)$, the enthalpy of mixing $\left(\Delta \mathrm{H}_{\mathrm{mix}}\right)$, and the atomic size difference $(\delta)[12,13]$. Sluggish diffusion explains the strengthening attribute of HEAs [14]. Moreover, a fine precipitate and a controlled grain structure are usually formed as a result of the sluggish diffusion effect. In contrast, the severe lattice distortion effect in HEAs results from the random arrangement of different sizes of atoms (making up the alloy) distributed in a crystal lattice [15,16]. The effect suggests that the pair distribution function directly relates to the distribution of the interatomic spacing on a local atomic level [15]. The "cocktail" effect indicates the possibility of achieving unexpected properties in an HEA system from mixing different elements in a chosen proportion [17]. Hence, resulting properties from this HEA are usually expected to surpass individual elemental properties that make up the system $[18,19]$. The properties of HEAs are known to be a result of the overall contributions of the constituent phases influenced by phase shape, phase distribution, and boundaries, as well as the properties of each phase [20]. The cocktail effect ranges from the atomic-scale, multielement composite effect to the microscale and multiphase composite effect [20].

There is no doubt that the basis of HEA design revolves around these so-called core effects. Hence, most HEAs studied have been derived from these basic principles [21-23]. Nevertheless, the validity of these core effects has been doubted by some researchers recently.

To date, the microstructural evolution of HEAs is still not well understood. This makes the prediction of processing-structure relationships quite a challenge. The design approach adopted by most researchers does not follow a specific logic; rather, a number of these alloys are a result of a trial-and-error approach. Although attempts have been made to categorize these alloys according to the intended application, there still exists a multitude of alloys exhibiting a wide range of properties. It is against this background that this review attempts to unravel some processing techniques used so far in synthesizing HEAs. This paper will also try to establish a structure-property relationship and link it to the processing route used. 


\section{Microstructural Evolution of HEAs Synthesized through the Melting and Casting Route}

HEAs have been fabricated using the melting and casting route. Table 1 is a compilation of some HEAs fabricated using the melting and casting route. In general, the melting and casting route is a liquid-state processing route with equilibrium or non-equilibrium cooling rates. An advantage of processing HEAs using the melting and casting route is the high temperatures that can be realized or needed to melt some elements that make up the HEA alloy [9]. Melting and casting can be achieved by a tilt casting furnace or suction casting. During the melting and casting process, the phase transformation of HEAs occurs during solidification (cooling). During solidification, phase evolution depends on the collective mobility or distribution of constituent elements making up the alloy [9]. However, the rate of cooling, differences in the local atomic arrangement, and the varying elemental diffusivity can influence the solid phase that is first to form and the microstructure of the alloys [24,25]. HEAs fabricated using the melting and casting route usually show dendritic microstructures with interdendritic segregations. For instance, $\mathrm{AlCoCrFeNi} \mathrm{HEAs}$ fabricated using the melting and casting route have been shown to exhibit BCC + B2 phases with dendritic microstructures [26,27]. Tian et al. [28] studied the effect of different cooling rates using arc-melting processing routes in the fabrication of AlCoCrFeNi HEAs. Both studies observed nanoparticles of the B2 phase within the grains of the single-phase BCC structure. Lv et al. [29] compared the effect of cooling rates on the microstructure of $\mathrm{Al}_{x} \mathrm{CoCrFeNi}$ HEAs using arc-melting and suction casting. The higher cooling rate of the suction casting resulted in refined columnar dendrite grains, while the arc-melting process led to a columnar cellular structure (see Figure 1). However, both processes led to the formation of BCC and FCC phases, with the inclusion of a B2 phase for arc-melting and Laves phases for suction casting. Thus, the melting and casting techniques with faster cooling rates favor the formation of a more dominant single phase and limit the precipitation of secondary phases [30]. Several studies have reported the cooling rate effects on HEAs fabricated using melting and casting [25,31,32]. 
Table 1. Phase evolution of HEAs fabricated using the melting and casting route.

\begin{tabular}{|c|c|c|c|c|}
\hline HEA Composition & Processing Method & Observed Phase(s) & Microstructures and Comments & Reference \\
\hline $\mathrm{AlCoCrFeNi}$ & Arc-melting & $\mathrm{BCC}$ & A dendritic structure is included. & {$[26,28]$} \\
\hline AlTiVCr & Arc-melting & $\begin{array}{l}\text { Single phase consisting of a B2 } \\
\text { phase and a disordered BCC phase }\end{array}$ & The $\mathrm{B} 2$ phase is more stable than the disordered $\mathrm{BCC}$ phase. & [33] \\
\hline AlCoFeNiTi & Arc-melting & $\mathrm{BCC}$ & A dendritic structure is included. & [34] \\
\hline TiVZrNbHf & Arc-melting & Single-phase BCC & & [35] \\
\hline $\mathrm{AlCrFeNiMo}_{0.2}$ & Vacuum Induction & $\mathrm{BCC}$ and $\mathrm{B} 2$ structure & $\begin{array}{c}\text { The BCC phase is FeCrMo-rich, while the } \mathrm{B} 2 \text { phase is a NiAl-rich } \\
\text { intermetallic compound. }\end{array}$ & [36] \\
\hline $\begin{array}{l}\mathrm{NbCrMoTiAl}_{0.5} \\
\mathrm{NbCrMoTiVAl}_{0.5} \mathrm{Si}_{0.3}\end{array}$ & Arc-melting & Simple BCC & $\begin{array}{l}\text { Mo segregates to the dendritic region. } \\
\mathrm{Cr}, \mathrm{Ti}, \mathrm{Al} \text {, and } \mathrm{Si} \text { segregate to the interdendritic regions. }\end{array}$ & [37] \\
\hline $\mathrm{Al}_{x} \mathrm{CoFeNiSi}(x>0.3)$ & Arc-melting & $\mathrm{BCC}$ & & [38] \\
\hline MoNbTaVW & Arc-melting & Single BCC & $\begin{array}{c}\text { Dendritic and interdendritic regions are present due to constitutional } \\
\text { segregation during solidification. }\end{array}$ & {$[39,40]$} \\
\hline $\begin{array}{l}\mathrm{Al}_{\mathrm{x}} \mathrm{CrFeMnNi} \mathrm{Mi}_{0.5} \\
\quad(\mathrm{x}=0.8-1.2)\end{array}$ & Arc-melting & $\mathrm{BCC}$ & & [41] \\
\hline $\mathrm{Fe}_{36} \mathrm{Mn}_{21} \mathrm{Cr}_{18} \mathrm{Ni}_{15} \mathrm{Al}_{10}$ & Arc-melting & Dual-phase 2 BCCs/B2 & $\begin{array}{l}\text { The matrix phase }(\mathrm{BCC}) \text { is rich in } \mathrm{Fe} \text { and } \mathrm{Cr} \text {. } \\
\text { The } \mathrm{B} 2 \text { phase is rich in } \mathrm{Ni} \text { and } \mathrm{Al} \text {. }\end{array}$ & [42] \\
\hline CoCrCuFeNi & Arc-melting & FCC & $\begin{array}{l}\text { The interface morphology would grow in planar, cellular, and dendrite if } \\
\text { the solidification rate is increased. }\end{array}$ & {$[18,43]$} \\
\hline $\begin{array}{c}\mathrm{CoCrFeNiV}_{0.5} \mathrm{C}_{\mathrm{x}} \\
(\mathrm{x}=0.01,0.02,0.03 \text {, and } 0.04)\end{array}$ & Arc-melting & FCC & $\begin{array}{c}\text { A large number of } \mathrm{M}_{7} \mathrm{C}_{3} \text {-type interstitial carbides are formed at an } \\
\text { annealing temperature of } 700^{\circ} \mathrm{C} \text { and above. }\end{array}$ & {$[44]$} \\
\hline $\mathrm{Fe}_{40} \mathrm{Mn}_{40} \mathrm{Co}_{10} \mathrm{Cr}_{10}$ & Vacuum induction & FCC & & [45] \\
\hline CrMnFeCoNi & Arc-melting, Vacuum Induction & FCC & $\begin{array}{c}\text { Precipitates of } \mathrm{M}_{23} \mathrm{C}_{6} \text { and the } \sigma \text { phase exist following prolonged } \\
\text { exposure at } 700{ }^{\circ} \mathrm{C} \text {. }\end{array}$ & {$[11,46]$} \\
\hline $\begin{array}{l}\mathrm{Al}_{\mathrm{x}} \mathrm{CoCrFeNi} \\
(\mathrm{x}=0-0.65)\end{array}$ & Arc-melting & FCC & $\begin{array}{l}\text { The FCC phase is transformed to the BCC phase with the presence of a } \\
\text { transition duplex FCC/BCC region as } \mathrm{Al} \text { increases. }\end{array}$ & [47] \\
\hline
\end{tabular}


Table 1. Cont.

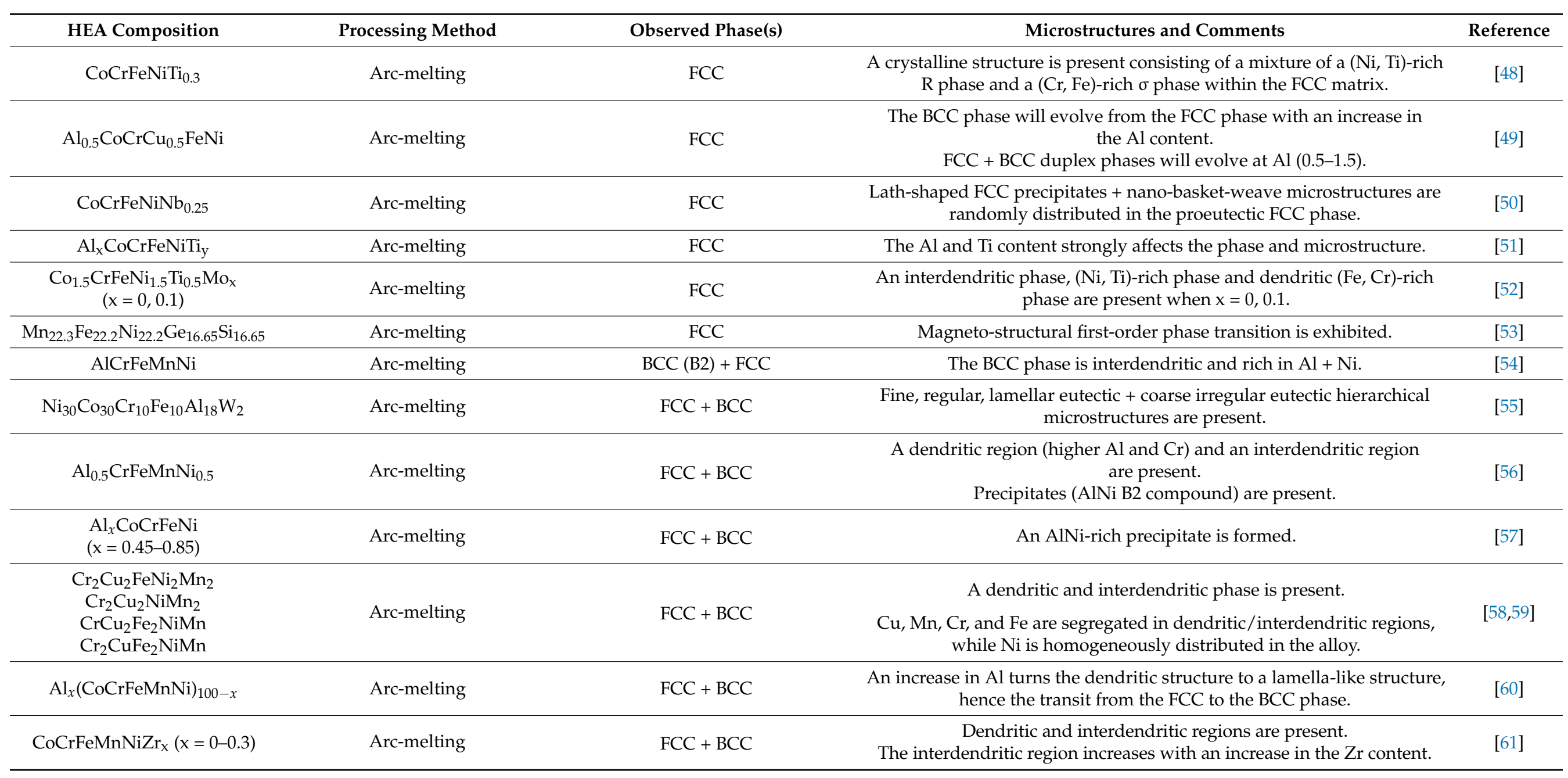


Table 1. Cont.

\begin{tabular}{|c|c|c|c|c|}
\hline HEA Composition & Processing Method & Observed Phase(s) & Microstructures and Comments & Reference \\
\hline $\begin{array}{l}\mathrm{AlCoCrCu} \mathrm{u}_{\mathrm{NiTi}} \\
\quad(\mathrm{x}=0.5-0.8)\end{array}$ & Arc-melting & $\mathrm{FCC}+\mathrm{BCC}$ & $\begin{array}{l}\text { Dendritic (contains compound impurities) and chrysanthemum-shape } \\
\text { dendrites are present. } \\
\text { Cu segregates in the interdendritic region. }\end{array}$ & {$[62]$} \\
\hline $\mathrm{CoCu}_{\mathrm{y}} \mathrm{FeNiTi}_{\mathrm{x}}$ & Arc-melting & 2 FCCs + BCC & $\begin{array}{c}\text { FCC } 1 \text { is } \mathrm{Cu} \text { rich, and FCC } 2 \text { is Co rich }(\mathrm{x}=1 / 3,3 / 7 \text {, and } 3 / 5) . \\
\text { The BCC phase is } \beta \text { Ti rich }(x=3 / 5) .\end{array}$ & {$[63]$} \\
\hline $\mathrm{CoCrFeNiCuAl}$ & Arc-melting & $\mathrm{FCC}+\mathrm{BCC}$ & $\begin{array}{l}\text { A cast-dendritic morphology is present. } \\
\text { The BCC phase is an ordered one. } \\
\text { of } 2 \text { FCC phases are present. }\end{array}$ & {$[64,65]$} \\
\hline $\begin{array}{l}\mathrm{Fe}_{50-\mathrm{X}} \mathrm{Mn}_{30} \mathrm{Co}_{10} \mathrm{Cr}_{10} \mathrm{~B}_{\mathrm{X}} \\
(\mathrm{x}=0,0.3,0.6,1.7 \mathrm{wt} \%)\end{array}$ & Arc-melting & $\mathrm{FCC}+\mathrm{BCC}$ & $\begin{array}{l}\text { The addition of boron promotes the formation of } \mathrm{M}_{2} \mathrm{~B} \text {-type borides } \\
\qquad(\mathrm{M}=\mathrm{Cr}, \mathrm{Fe})\end{array}$ & {$[66]$} \\
\hline $\mathrm{AlCrCuFeMnNi}$ & Vacuum Induction & $2 \mathrm{BCCs}(\mathrm{B} 2+\mathrm{A} 2)+\mathrm{FCC}$ & $\begin{array}{l}\text { The 2BCC phase is formed by spinodal decomposition, i.e., } \mathrm{B} 2 \text { (NiAl } \\
\text { dendrite matrix) and A2 (Cr-Fe rich) embedded precipitate. }\end{array}$ & {$[67]$} \\
\hline $\mathrm{Al}_{0.5} \mathrm{CoCrFeNi}$ & Arc-melting, Vacuum Induction & FCC + BCC crystalline structures & $\begin{array}{l}\text { The presence of the } \mathrm{Al}-\mathrm{Ni} \text {-rich phase decreases as the aging temperature } \\
\text { increases and, hence, leads to an increase in the amount of } \\
\qquad \mathrm{Al}-(\mathrm{Ni}, \mathrm{Co}, \mathrm{Cr}, \mathrm{Fe}) .\end{array}$ & {$[68,69]$} \\
\hline $\mathrm{Al}_{0.5} \mathrm{CrCuNiV}$ & Arc-melting & $\mathrm{FCC}+2 \mathrm{BCCs}+\mathrm{B} 2$ & $\begin{array}{l}\text { A dendrite rich in } \mathrm{Cr} \text { and } \mathrm{V} \text { is present. } \\
\text { The incorporation of } \mathrm{Cu} \text { into the 2-BBC phase differentiates it from } \\
\text { the } \mathrm{B} 2 \text { phase. }\end{array}$ & {$[71]$} \\
\hline $\mathrm{AlCoCrFeNi}_{2.1}$ & Vacuum Induction & Dual-phase FCC + BCC (B2) & - & [72] \\
\hline $\begin{array}{l}\mathrm{AlCrCuFeNi} \\
(0.6 \leq x \leq 1.4)\end{array}$ & Arc-melting & $\mathrm{FCC}+\mathrm{BCC}$ & The content of Ni has a significant effect on the HEA microstructure. & {$[73,74]$} \\
\hline
\end{tabular}



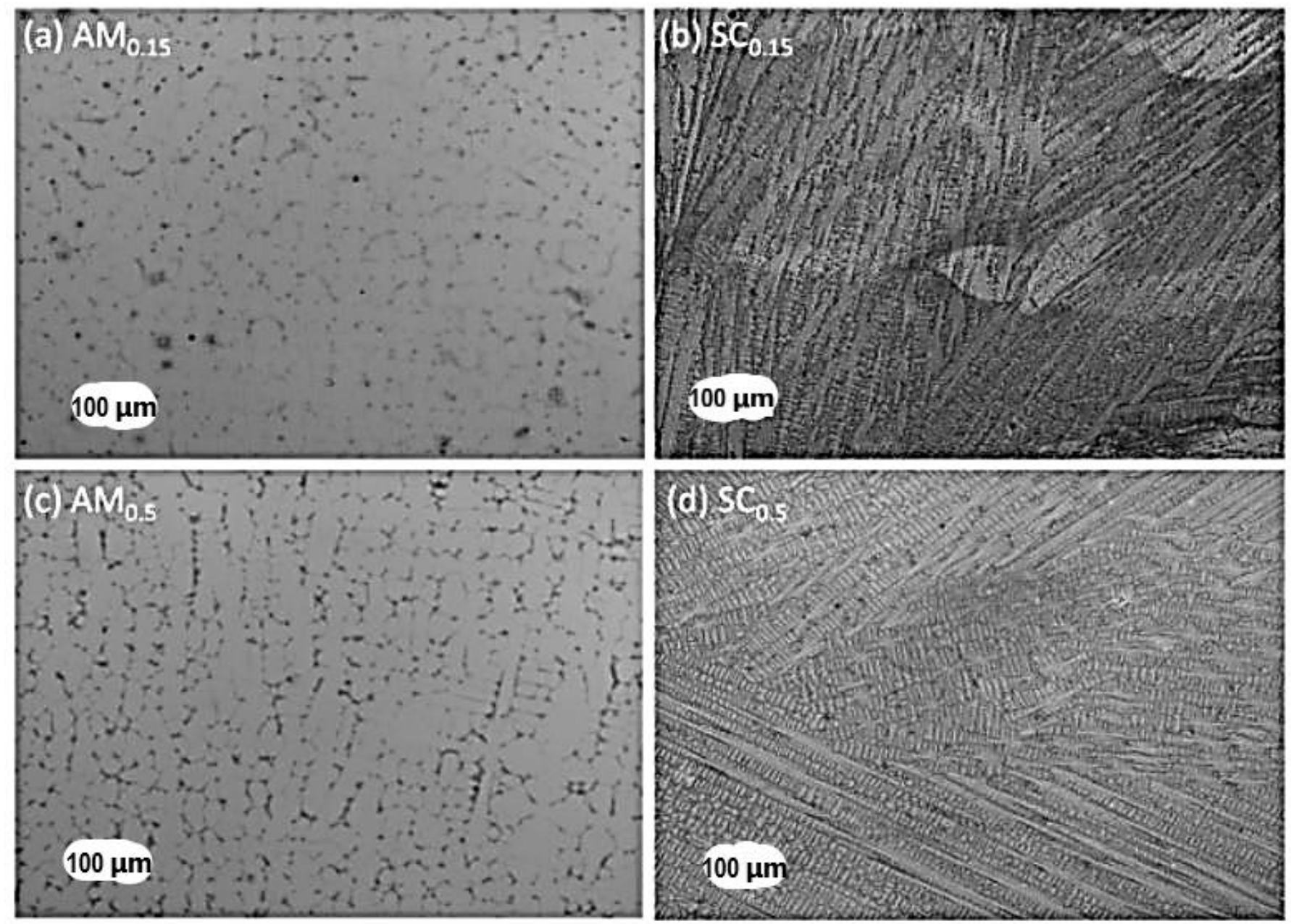

Figure 1. $\mathrm{OM}$ micrographs of arc-melting $\left(\mathrm{AM}_{x}\right)$ and suction-casting $\left(\mathrm{SC}_{x}\right)$ alloys $(\mathrm{x}=0.15$ and 0.5$)$. (a) Columnar cellular structure and (c) non-equiaxed columnar dendrite by arc-melting; (b) and (d) columnar dendrite grains by suction casting [29].

From another perspective, HEA phase formation during fabrication via the melting and casting route is suggested to hinge on binary constituent pairs rather than individual constituent elements $[75,76]$. An HEA system such as the AlCoCrFeNi alloy forms a BCC structure after processing; although among the constituent elements, only $\mathrm{Cr}$ and $\mathrm{Fe}$ have BCC crystal structures. The AlNi pair, from the possible binaries in the AlCoCrFeNi system, serves as the primary crystal structure in the AlCoCrFeNi HEA. This is due to the similar lattice parameter between AlNi $(0.28810 \mathrm{~nm})$ and $\mathrm{AlCoCrFeNi}(0.289675 \mathrm{~nm})[77,78]$. In addition, AlNi has the largest negative enthalpy of formation among all the binary pairs in AlCoCrFeNi [79-81]. The AlNi binary pair stabilizes over a wide composition field from $1638{ }^{\circ} \mathrm{C}$ down to room temperature and can dissolve other constituent elements [82,83]. The other elements, therefore, dissolve into the primary lattice due to their chemical compatibility and mixing entropy effect [84]. During solidification, $\mathrm{Cr}$ having the highest melting point is the first element to solidify. Cr remains segregated from the liquid mixture up to $1350{ }^{\circ} \mathrm{C}$ at the equiatomic composition $[85,86]$. In contrast, $\mathrm{Al}$ has the lowest melting temperature and thus has the highest diffusivity during solidification. The effect of $\mathrm{Al}$ addition on 3d transition metal-based HEAs such as AlCoCrFeNi been studied [87-89]. The increasing quantity of $\mathrm{Al}$ promotes the formation of the BCC phase [89-91]. Moreover, Wang et al. [92] and Rogström et al. [93] observed that the AlCoCrFeNi HEA exhibits a spinodal microstructure of an A2 ((Cr, Fe)-rich) disordered solid solution and a modulated 
B2 ((Al, Ni)-rich) ordered solid solution. The A2 phase forms at temperatures below $600{ }^{\circ} \mathrm{C}$, while the B2 phase forms at higher temperatures [92].

Some examples of HEAs that exhibit a single-phase FCC structure after melting and casting are the $\mathrm{CoCrFeMnNi} H E A$ structure $[14,94]$, the $\mathrm{Al}_{x} \mathrm{CoCrCuFeNi}$ alloy system [95,96], the CoCrCuFeNi HEA [97,98], the $\mathrm{FeCoNiCrCuO}_{0.5} \mathrm{Al}_{x} \mathrm{HEA}[49]$, and the $\mathrm{Al}_{\mathrm{x}} \mathrm{CoCrFeNiTi}_{\mathrm{y}} \mathrm{HEA}[51,99]$. The binary constituents in these HEAs encourage the formation of the FCC phase. In addition, the addition of elements such as $\mathrm{Cu}$ and Ti stabilizes the FCC phase $[100,101]$. In the $\mathrm{Al}_{x} \mathrm{CoCrFeNi}$ alloy system, the addition of Ti promotes phase evolution from the BCC to an FCC phase [81]. Furthermore, when $\mathrm{Al}$ in $\mathrm{AlCoCrFeNi}$ is replaced with $\mathrm{Cu}$ to form the $\mathrm{CoCrCuFeNi}$ alloy, the FCC phase forms instead of an $\mathrm{A} 2+\mathrm{B} 2$ structure associated with $\mathrm{AlCoCrFeNi}$. CuCo, $\mathrm{CuNi}, \mathrm{CoNi}, \mathrm{FeNi}$, and $\mathrm{CoFe}$, which make up the binary constituents in the $\mathrm{CoCrCuFeNi}$ alloy, all have an FCC structure and promote the FCC phase. In addition, the use of $\mathrm{Mn}$ to form $\mathrm{CoCrFeMnNi}$ also leads to a single-phase FCC structure [102].

\section{Powder Metallurgy}

\subsection{Mechanical Alloying (MA)}

MA is a solid-state process that allows the dispersion of insoluble phases and the addition of reactive alloying elements to produce composite metal powders with controlled microstructures. In this process, a high-energy stirred ball mill or shaker mill is used to subject blended powders of known particle size to a compressive force to agglomerate the powders. The mechanical alloying process can be grouped into five different stages: the initial stage, a period of welding, an equiaxed particle formation period, the start of random welding orientation, and steady-state processing [103]. Hence, these periods can be explained in terms of [103] (a) the distribution of the powder and shape, (b) how hard the material is on the ball surface, (c) the microstructure of the powder and material on the ball surface, and (d) the material division between ball surfaces and free powders. The formation of composite particles and the refinement of structure occur over time as a result of repeated welding and fracturing of free powder particles.

MA has been given more preference in the literature recently compared to conventional methods such as melting and casting. It does aid the homogeneous distribution of particle size, consolidation, and a reduction in grain size and helps in proper densification of elemental powders [104]. The mechanical energy input as well as the rate of work hardening among the material influences the rate of structural refinement in HEAs. These thus have a positive effect on the resulting mechanical properties of HEAs. Hence, the MA technique is considered a more convenient and cost-effective way of synthesizing nano-crystalline materials with a uniform microstructure [104].

\subsection{Spark Plasma Sintering (SPS)}

SPS uses a direct current (DC) pulse voltage and current during compaction of asmilled alloy powders to produce a bulk alloy in the solid state [105]. Spark plasma and spark impact pressure are used to generate high temperatures between the particles, causing melting of the surface of the particles during the sintering process [106]. Chakraborty et al. [107] classified the mechanism of sintering of a bulk alloy using SPS into five stages: generation of plasma, heating, melting, sputtering of the molten particles, and neck growth. The as-milled powder is directly charged into a graphite die through which current and uniaxial force or pressure are applied simultaneously, resulting in a fully dense material with outstanding mechanical properties [108]. Densification is achieved for both conductive and nonconductive powders in a short time due to the fast heating rate [106]. Application of high heating and cooling rates in SPS enhances densification and promotes the diffusion mechanism, which helps to maintain the powders' intrinsic properties in a fully dense state [108]. A higher cooling rate reduces the level of micro-segregation in the alloy and leads to refinement of grain size, which is achievable in SPS [109]. Hence, the need for heat-treating SPS-fabricated HEAs might be unnecessary. This is in contrast 
with the as-cast microstructure having the possibility of generating a dendritic microstructure during the solidification process [8]. Therefore, SPS present tremendous potential and can sinter a fully dense and nearly single-phase alloy with a refined microstructure from elemental powder. The microstructure and phases in the final sintered products are significantly influenced by the processing parameters.

The SPS method is widely used, especially to synthesize nano-crystalline microstructures, advanced ceramics, and composite materials, owing to its advantages over conventional sintering techniques [110]. The sintering system not only offers ease of operation but also results in less grain growth in the microstructure. Hence, this leads to an improved microstructure, further leading to better resulting mechanical properties when compared to the melting and casting route. Solid solution strengthening is achieved through this fabrication technique, which also has a positive impact on the mechanical properties of HEAs. These are some of the reasons many researchers lately prefer SPS as a mode of compacting powders, in addition to its significant advantages such as shorter processing time [110], flexible sintering temperature, avoidance of porosity, easy control of sintering parameters, and energy-efficient processing. Figure 2 shows a schematic diagram of the SPS process.

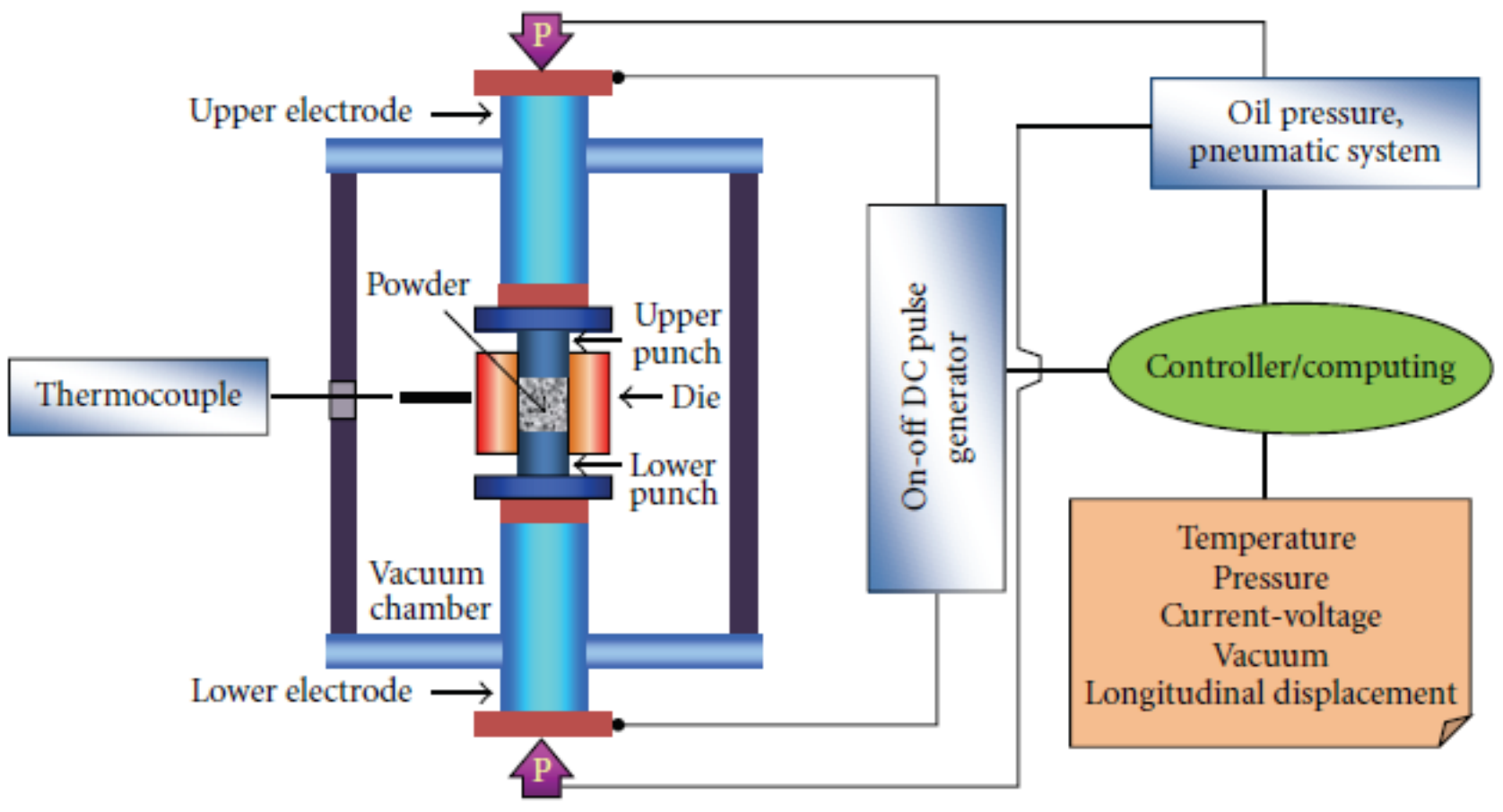

Figure 2. Schematic diagram of the SPS process [108].

\subsection{Microstructural Evolution of HEAs Synthesized Using Powder Metallurgy}

The PM synthesis route through MA and consolidation by SPS has been used in the fabrication of HEAs $[10,111,112]$. The MA and SPS techniques are solid-state processing routes mostly used to achieve nanocrystalline HEAs [113]. The MA process is a nonequilibrium process and thus leads to the formation of metastable phases. Table 2 shows a summary of evolved phases of some HEAs fabricated through MA and SPS. 
Table 2. Phase evolution of HEAs after MA and SPS.

\begin{tabular}{|c|c|c|c|c|c|}
\hline \multirow{2}{*}{ HEA Alloy } & \multirow{2}{*}{ MA Parameters } & \multirow{2}{*}{ SPS Parameters } & \multicolumn{2}{|c|}{ Phase Evolution } & \multirow{2}{*}{ Reference } \\
\hline & & & MA & After SPS & \\
\hline $\mathrm{FeNiCrCo}_{0.3} \mathrm{Al}_{0.7}$ & $\begin{array}{c}\mathrm{S}=300 \mathrm{rpm} \\
\mathrm{BPR}=10: 1 \\
\mathrm{D}=45 \mathrm{~h} \\
\mathrm{GM}=\text { stainless steel vial, tungsten } \\
\text { carbide balls }\end{array}$ & $\begin{array}{c}\mathrm{ST}=600^{\circ} \mathrm{C}(4 \mathrm{~min}) \\
\mathrm{HR}=75^{\circ} \mathrm{C} \mathrm{m^{-1 }} \\
\mathrm{ST}=600 \text { to } 1000^{\circ} \mathrm{C}\left(\text { at } \mathrm{HR}=50^{\circ} \mathrm{C} \mathrm{min}^{-1} \text { in }\right. \\
4 \mathrm{~min}) \\
\left(1000^{\circ} \mathrm{C} \text { in } 8 \mathrm{~min}\right) \\
\mathrm{P}=30 \mathrm{MPa}\end{array}$ & $\mathrm{BCC}$ & $\mathrm{BCC}+\mathrm{FCC}$ & [114] \\
\hline $\begin{array}{c}\mathrm{AlCoCrFeNiSi}_{\mathrm{x}}(\mathrm{x}=0.3 \\
0.6 \text {, and } 0.9)\end{array}$ & $\begin{array}{c}\mathrm{S}=300 \mathrm{rpm} \\
\mathrm{BPR}=10: 1 \\
\mathrm{D}=20 \mathrm{~h} \\
\mathrm{GM}=\text { tungsten carbide vial }\end{array}$ & $\begin{array}{c}\mathrm{ST}=570-800{ }^{\circ} \mathrm{C} \\
\mathrm{HR}=100{ }^{\circ} \mathrm{C} \min ^{-1} \\
\mathrm{ST}=800^{\circ} \mathrm{C}-1000^{\circ} \mathrm{C} \\
\mathrm{HR}=50{ }^{\circ} \mathrm{C} \min ^{-1} \\
\left(1000{ }^{\circ} \mathrm{C} \text { in } 5 \mathrm{~min}\right) \\
\mathrm{P}=60 \mathrm{MPa}\end{array}$ & $\mathrm{BCC}$ & $\mathrm{BCC}+\mathrm{FCC}+$ sigma phase & [115] \\
\hline $\mathrm{Al}_{0.4} \mathrm{FeCrCo}_{1.5} \mathrm{NiTi}_{0.3}$ & $\begin{array}{c}\mathrm{S}=300 \mathrm{rpm} \\
\mathrm{BPR}=10: 1 \\
\mathrm{D}=50 \mathrm{~h}(\text { dry })+5 \mathrm{~h} \text { (wet) }\end{array}$ & $\begin{array}{c}\mathrm{ST}=1000^{\circ} \mathrm{C}(10 \mathrm{~min}) \\
\mathrm{P}=30 \mathrm{MPa}\end{array}$ & $\mathrm{BCC}+\mathrm{FCC}$ & FCC (major) + BCC (minor) & [116] \\
\hline $\mathrm{Al}_{0.5} \mathrm{CrFeNiCo}_{0.3} \mathrm{C}_{0.2}$ & $\begin{array}{c}\mathrm{S}=300 \mathrm{rpm} \\
\mathrm{BPR}=10: 1 \\
\mathrm{D}=38 \mathrm{~h} \text { dry }+4 \mathrm{~h} \text { wet }(42 \mathrm{~h}) \\
\mathrm{GM}=\text { stainless steel vial, tungsten } \\
\text { carbide balls }\end{array}$ & $\begin{array}{c}\mathrm{ST}=600{ }^{\circ} \mathrm{C}(4 \mathrm{~min}) \\
\mathrm{ST}=600-900{ }^{\circ} \mathrm{C} \\
\mathrm{HR}=75^{\circ} \mathrm{C} \mathrm{m^{-1 }} \\
\mathrm{ST}=900-1000^{\circ} \mathrm{C} \\
\mathrm{HR}=50{ }^{\circ} \mathrm{C} \mathrm{min}-1 \\
\left(1000{ }^{\circ} \mathrm{C} \text { in } 8 \mathrm{~min}\right) \\
\mathrm{P}=30 \mathrm{MPa}\end{array}$ & $\begin{array}{c}\text { BCC + FCC within first } \\
38 \mathrm{~h} \mathrm{MA}\end{array}$ & FCC (major) + BCC & [117] \\
\hline
\end{tabular}


Table 2. Cont.

\begin{tabular}{|c|c|c|c|c|c|}
\hline \multirow{2}{*}{ HEA Alloy } & \multirow{2}{*}{ MA Parameters } & \multirow{2}{*}{ SPS Parameters } & \multicolumn{2}{|c|}{ Phase Evolution } & \multirow{2}{*}{ Reference } \\
\hline & & & MA & After SPS & \\
\hline \multirow[t]{2}{*}{ CoCrFeNiMnAl } & $\begin{array}{c}\mathrm{S}=250 \mathrm{rpm} \\
\mathrm{BPR}=15: 1 \\
\mathrm{D}=60 \mathrm{~h} \\
\text { Annealed from } 500-1000^{\circ} \mathrm{C}\end{array}$ & $\begin{array}{c}\mathrm{ST}=800{ }^{\circ} \mathrm{C}(10 \mathrm{~min}) \\
\mathrm{P}=50 \mathrm{MPa}\end{array}$ & BCC & $\mathrm{BCC}+\mathrm{FCC}$ & [118] \\
\hline & $\begin{array}{c}\mathrm{GM}=\text { stainless steel vial and balls, } \\
\text { N-heptane PCA }\end{array}$ & & & & \\
\hline $\mathrm{Ni}_{1.5} \mathrm{Co}_{1.5} \mathrm{CrFeTi}_{0.5}$ & $\begin{array}{c}\mathrm{S}=250 \mathrm{rpm} \\
\mathrm{BPR}=10: 1 \\
\mathrm{D}=30 \mathrm{~h} \text { dry }+2 \mathrm{~h} \text { wet (toluene) }(32 \mathrm{~h}) \\
\mathrm{GM}=\text { hardened tool steel vial and } \\
\text { hardened balls }\end{array}$ & $\begin{array}{c}\mathrm{ST}=1000^{\circ} \mathrm{C} \text { at } \mathrm{HR}=100{ }^{\circ} \mathrm{C} \mathrm{min}^{-1} \\
\mathrm{ST}=1000-1100^{\circ} \mathrm{C} \text { at } \mathrm{HR}=50^{\circ} \mathrm{C} \mathrm{min}^{-1} \\
\mathrm{ST}=1100-1150{ }^{\circ} \mathrm{C} \text { at } \mathrm{HR}=20^{\circ} \mathrm{C} \mathrm{min}^{-1} \\
\left(1150^{\circ} \mathrm{C} \text { in } 20 \mathrm{~min}\right) \\
\mathrm{P}=30 \mathrm{MPa}\end{array}$ & $\mathrm{BCC}+2$ FCCs & FCC + oxide & [119] \\
\hline $\mathrm{AlCuNiFeCr}$ & $\begin{array}{c}\mathrm{S}=580 \mathrm{rpm} \\
\mathrm{BPR}=1: 10 \\
\mathrm{D}=5 \mathrm{~h} \\
\mathrm{GM}=\text { hardened } \text { ShH-15 steel, gasoline } \\
\text { medium }\end{array}$ & $\begin{array}{c}\mathrm{ST}=700,800 \text {, and } 900^{\circ} \mathrm{C}(15 \mathrm{~min}) \\
\mathrm{P}=150 \mathrm{MPa}\end{array}$ & $\mathrm{BCC}$ & $\begin{array}{c}\mathrm{B} 2+\mathrm{FCC}+(\mathrm{Fe}, \mathrm{Cr})_{23} \mathrm{C}_{6} \\
\text { after SPS }\end{array}$ & [120] \\
\hline $\mathrm{Nb}_{25} \mathrm{Mo}_{25} \mathrm{Ta}_{25} \mathrm{~W}_{25}$ & $\begin{array}{l}\mathrm{S}=400 \mathrm{rpm} \\
\mathrm{BPR}=15: 1\end{array}$ & $\mathrm{ST}=1600{ }^{\circ} \mathrm{C}(8 \mathrm{~min})$ & & & \\
\hline $\mathrm{Ti}_{8} \mathrm{Nb}_{23} \mathrm{Mo}_{23} \mathrm{Ta}_{23} \mathrm{~W}_{23}$ & $\begin{array}{c}\mathrm{D}=60 \mathrm{~h} \\
\mathrm{GM}=\text { tungsten carbide vials, acetone } \\
\text { PCA }\end{array}$ & $\mathrm{P}=35 \mathrm{MPa}$ & $\mathrm{BCC}$ & BCC & [121] \\
\hline CoNiFeAlTi & $\begin{array}{c}\mathrm{S}=300 \mathrm{rpm} \\
\mathrm{BPR}=10: 1 \\
\mathrm{D}=4 \mathrm{~h} \text { wet }+45 \mathrm{~h} \text { dry }(49 \mathrm{~h}) \\
\mathrm{GM}=\text { stainless steel vials and tungsten } \\
\text { carbide balls, no PCA }\end{array}$ & $\begin{array}{c}\mathrm{ST}=1000^{\circ} \mathrm{C}(8 \mathrm{~min}) \\
\mathrm{HR}=90^{\circ} \mathrm{C} \mathrm{min}^{-1} \\
\mathrm{P}=30 \mathrm{MPa}\end{array}$ & $\mathrm{BCC}+\mathrm{FCC}$ & $\begin{array}{l}\mathrm{BCC}(\mathrm{B} 2)+\mathrm{FCC}+\mathrm{Al}_{3} \mathrm{Ti} \\
\text { intermetallics after SPS }\end{array}$ & [122] \\
\hline
\end{tabular}


Table 2. Cont.

\begin{tabular}{|c|c|c|c|c|c|}
\hline \multirow{2}{*}{ HEA Alloy } & \multirow{2}{*}{ MA Parameters } & \multirow{2}{*}{ SPS Parameters } & \multicolumn{2}{|c|}{ Phase Evolution } & \multirow{2}{*}{ Reference } \\
\hline & & & MA & After SPS & \\
\hline $\mathrm{Al}_{0.3} \mathrm{CoCrFeMnNi}$ & $\begin{array}{c}\mathrm{S}=200 \mathrm{rpm} \\
\mathrm{BPR}=15: 1 \\
\mathrm{D}=36 \mathrm{~h} \\
\mathrm{GM}=\text { stainless steel vials and balls, } \\
\text { N-heptane PCA }\end{array}$ & $\begin{array}{c}\mathrm{ST}=800,900, \text { and } 1000^{\circ} \mathrm{C}(10 \mathrm{~min}) \\
\mathrm{HR}=100{ }^{\circ} \mathrm{C} \mathrm{min}^{-1} \\
\mathrm{P}=50 \mathrm{MPa}\end{array}$ & FCC & BCC (B2) after SPS & [123] \\
\hline $\begin{array}{c}(\mathrm{CuCrFeTiZn})_{100-\mathrm{x}} \mathrm{Pb}_{\mathrm{x}} \\
(\mathrm{x}=0,5,10, \text { and } 20)\end{array}$ & $\begin{array}{c}\mathrm{S}=200 \mathrm{rpm} \\
\mathrm{BPR}=20: 1 \\
\mathrm{D}=44 \mathrm{~h} \\
\mathrm{GM}=\text { tungsten carbide vials and balls }\end{array}$ & $\begin{array}{c}\mathrm{ST}=800,900, \text { and } 1000^{\circ} \mathrm{C} \\
\mathrm{HR}=150{ }^{\circ} \mathrm{C} \mathrm{min}^{-1} \\
\mathrm{P}=50 \mathrm{MPa}\end{array}$ & $\mathrm{Fe}-\mathrm{Cr}(\mathrm{BCC})+\mathrm{Cu}-\mathrm{Zn}(\mathrm{FCC})$ & $\mathrm{Fe}-\mathrm{Cr}(\mathrm{BCC})+\mathrm{Cu}-\mathrm{Zn}(\mathrm{FCC})$ & [124] \\
\hline
\end{tabular}

Legend: S, milling speed; BPR, ball-to-powder ratio; D, milling duration; ST, sintering temperature; HR, heating rate; $\mathrm{P}$, compression pressure; GM, grinding media. 
The binary-phase diagrams of constituent elements and the thermodynamic concept of mixing enthalpies in an HEA system help understand or predict possible phases during MA [125]. The energy involved during the MA process generates heat and influences the phases that form. Typically, an alloy system would tend toward phases for which free energy is the lowest. So, for the desired phase(s), it is imperative to achieve the right balance of parameters used in the MA process, such as milling duration, ball-to-powder ratio (BPR), and the grinding media. Chen et al. [114] studied the alloying behavior, microstructure, and mechanical properties of $\mathrm{FeNiCrCo}_{0.3} \mathrm{Al}_{0.7}$ HEA fabricated using the MA and SPS route. The FeNiCrCo $\mathrm{F}_{0.3} \mathrm{Al}_{0.7}$ HEA formed a refined and homogeneous supersaturated BCC solid solution after $45 \mathrm{~h}$ of milling. After the first $6 \mathrm{~h}$ of milling, Al and Co rapidly dissolved into the solution compared to the other elements, as depicted in Figure 3. Even though $\mathrm{Al}$ and $\mathrm{Co}$ quantities were less, their rapid diffusion could be attributed to their relatively low melting temperatures.

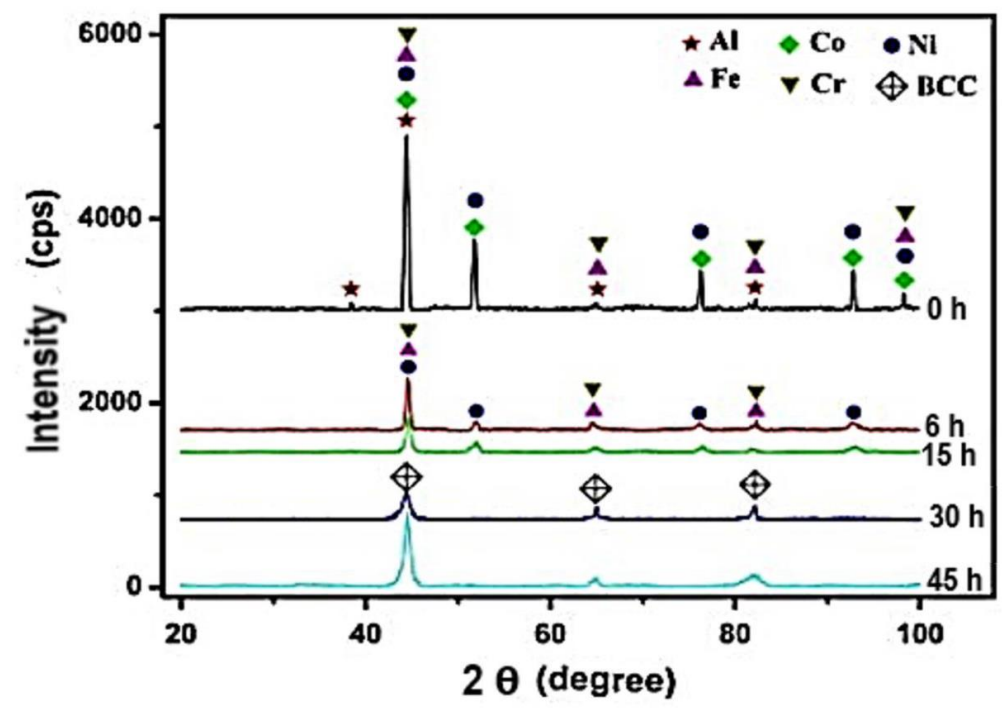

Figure 3. XRD pattern of $\mathrm{FeNiCrCo}_{0.3} \mathrm{Al}_{0.7}$ with different milling times [114].

Other elements such as $\mathrm{Cr}$ and Fe dissolved into solution as the milling time increased. $\mathrm{Cr}$ and Fe exhibit a BCC crystal structure and therefore may accommodate other elements without much expansion [114,126]. Additionally, $\mathrm{Cr}$ has the highest melting temperature in the HEA system and thus diffuses the slowest during the MA process. The MA process is known to include repeated welding and fracturing, leading to crystallite refinement. Since HEAs are baseless systems composed of elements with different atomic sizes, the size mismatch effect occurs during the MA process. Increasing milling time during the MA process leads to an increase in dislocation density and lattice strain caused by the severe plastic deformation occurring, and the size mismatch effect and increase in the grain boundary fraction owing to the crystallite refinement [127].

Vaidya et al. [81] studied the effect of the elemental addition sequence on the phase evolution of the nanocrystalline $\mathrm{AlCoCrFeNi} \mathrm{HEA}$ system using the MA processing technique. Three different classes of binaries were selected as initial starting phases, while other constituent elements were added stepwise in varying sequences until quinary systems were formed. The binaries included B2 (AlNi, AlCo and AlFe), BCC (FeCr), and FCC (CoNi and FeNi) phases. For example, in AlCo starting as a binary lattice, the more the FCC phase from the dual BCC + FCC phase expands, the more Al dissolves into the solid solution. The addition of Ni to AlCo (B2) favors an FCC structure instead of a stabilizing B2 structure. This indicates a high tendency of an FCC solid solution of Ni (Co) forming than an intermetallic AlNiCo phase. The formation of AlCoNiFeCr from AlCoNi due to the addition of Fe and $\mathrm{Cr}$ destabilizes the FCC phase. As a result, the BCC phase evolves from FCC to form BCC (major) + FCC as the final microstructure. Praveen et al. [128] also reported a similar phase during MA of $\mathrm{CoCrFeNi}$ alloy. There were variations in the 
amount of BCC and FCC present at the end of each sequence in the CoCrFeNi HEA fabricated. The resulting microstructure of $\mathrm{AlCoNiFeCr} \mathrm{HEA,} \mathrm{BCC} \mathrm{+} \mathrm{FCC,} \mathrm{remained} \mathrm{consistent}$ with a wide range of sequences despite variation in both alloying sequence and milling duration. This is contrary to the single-phase BCC formation reported when FeNiCoCrAl, $\mathrm{FeCrAlNiCo}, \mathrm{AlNiCoFeCr}$ alloy sequences from three different binaries were processed using arc-melting $[129,130]$. In addition, the base alloy sequence AlCoCrFeNi exhibited a single-phase BCC structure when fabricated using arc-melting [129].

It is noteworthy that the alloy sequences starting with the BCC phase showed a larger amount of FCC phase fractions at the end of milling, and this phase becomes stable when nanocrystalline $\mathrm{Ni}$ is added. Therefore, it can be inferred that the FCC phase is promoted by $\mathrm{Ni}$ and $\mathrm{Co}$ addition, unless when $\mathrm{Co}$ is added immediately after $\mathrm{Al}$ owing to Co's strong affinity to Al. The BCC phase is stabilized by the addition of $\mathrm{Al}$ during sequential alloying irrespective of the position at which it is added $[20,120]$. Cr favors BCC phase formation, while Fe has the least influence on phase formation due to a less negative $\Delta \mathrm{H}_{\mathrm{avg}}$ and the lowest atomic radius. It can be deduced that the initial structure of the binary alloy, the addition of individual elements, and the order of mixing constituents are some of the factors that influence the phase evolution during sequential alloying in the MA route.

Furthermore, the formation of the supersaturated BCC solid solution in the $\mathrm{FeNiCrCo}_{0.3} \mathrm{Al}_{0.7} \mathrm{HEA}$ is attributed to the energy stored in the grain boundaries, high entropy of mixing, and solid solubility extension [114,131]. Partial BCC phases in the $\mathrm{FeNiCrCo}_{0.3} \mathrm{Al}_{0.7} \mathrm{HEA}$ after MA evolved to a more stable FCC phase during the SPS process at $1000{ }^{\circ} \mathrm{C}$. The annihilation of defects introduced into the structure owing to the high-energy ball milling during the MA process leads to reordering at high temperatures. As a result, defects introduced by severe plastic deformation during MA are nearly annihilated after consolidation by SPS, which can also contribute to phase evolution during SPS. Ji et al. [112] obtained a BCC solid solution for CoCrFeNiAl HEA after milling for $60 \mathrm{~h}$. From the study, the BCC solid solution formed during the first $30 \mathrm{~h}$ and was only refined as milling progressed to $60 \mathrm{~h}$. After SPS consolidation at $900{ }^{\circ} \mathrm{C}, \mathrm{BCC}$ and FCC phases formed. Kumar et al. [115] also achieved a BCC supersaturated solid solution by MA of $\mathrm{AlCoCrFeNiSi}_{\mathrm{x}}$ for $20 \mathrm{~h}$. The studied alloy was quite similar to that of Ji et al. However, a BCC solid solution was attained after a shorter milling duration $(20 \mathrm{~h})$ compared to the $60 \mathrm{~h}$ done by Ji et al. [112]. This goes to show that milling speed also influences the phases formed during the MA process. Kumar et al. [115] used a milling speed of $300 \mathrm{rpm}$, while Ji et al. [112] used a speed of $250 \mathrm{rpm}$. Major phases composed of BCC, FCC, and sigma were obtained in the $\mathrm{AlCoCrFeNiSi}_{\mathrm{x}}(\mathrm{x}=0.3,0.6$, and 0.9$)$ fabricated by MA after SPS consolidation at $1000{ }^{\circ} \mathrm{C}$. However, only BCC and sigma phases were observed in $\mathrm{AlCCrFeNiSi}_{0.9}$. Figure 4 shows the XRD pattern of $\mathrm{AlCoCrFeNiSi}_{x}$ after SPS. Si is known to be a $\mathrm{BCC}$ former and stabilizer. $\mathrm{Si}$, having the ability to occupy another element spot in the grain boundary, shows that more atoms will be replaced with an increase in the $\mathrm{Si}$ content [115]. This, thereby, introduced lattice distortion and lattice strain in the system, while it destabilized the FCC phase. 


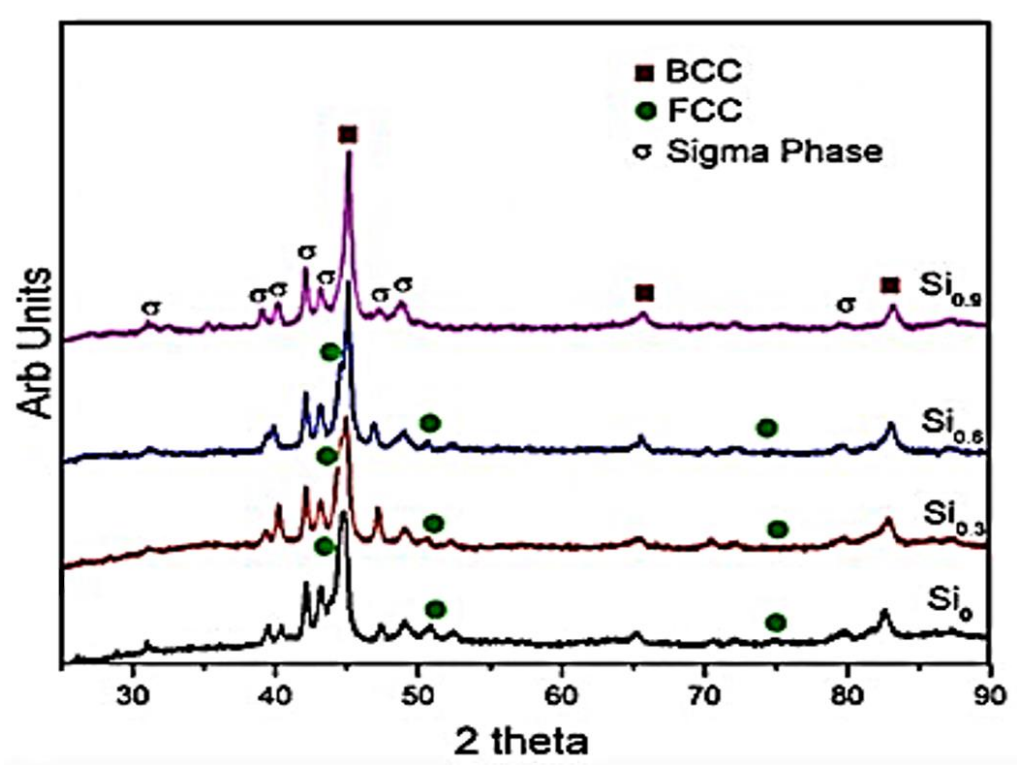

Figure 4. XRD pattern of AlCoCrFeNiSi $i_{x}$ after SPS, where $x=0,0.3,0.6$, and 0.9 [115].

\section{Microstructural Evolution of HEAs Fabricated by Additive Manufacturing (AM)}

AM has become a mainstream manufacturing process because of its flexible design optimization and processing advantages. The production of customized parts and the ability to control the microstructure in a specific site are possible in this processing route. The higher heating and cooling rates associated with AM promote chemical homogeneity in alloys by restricting diffusion to avoid undesired multiple phase transformations during cooling [132]. Solidification mainly takes place along the building direction and is predominantly epitaxial. The successive building process in thin layers by local heat input characterizes the microstructures as a result of rapid and directional solidification. Factors such as powder flowability, laser power, powder thickness and shape, scan spacing, and volumetric energy density (VED) all play an important role in determining the resulting microstructure in AM technology. Figure 5 below shows the schematic representation of additive manufacturing techniques.

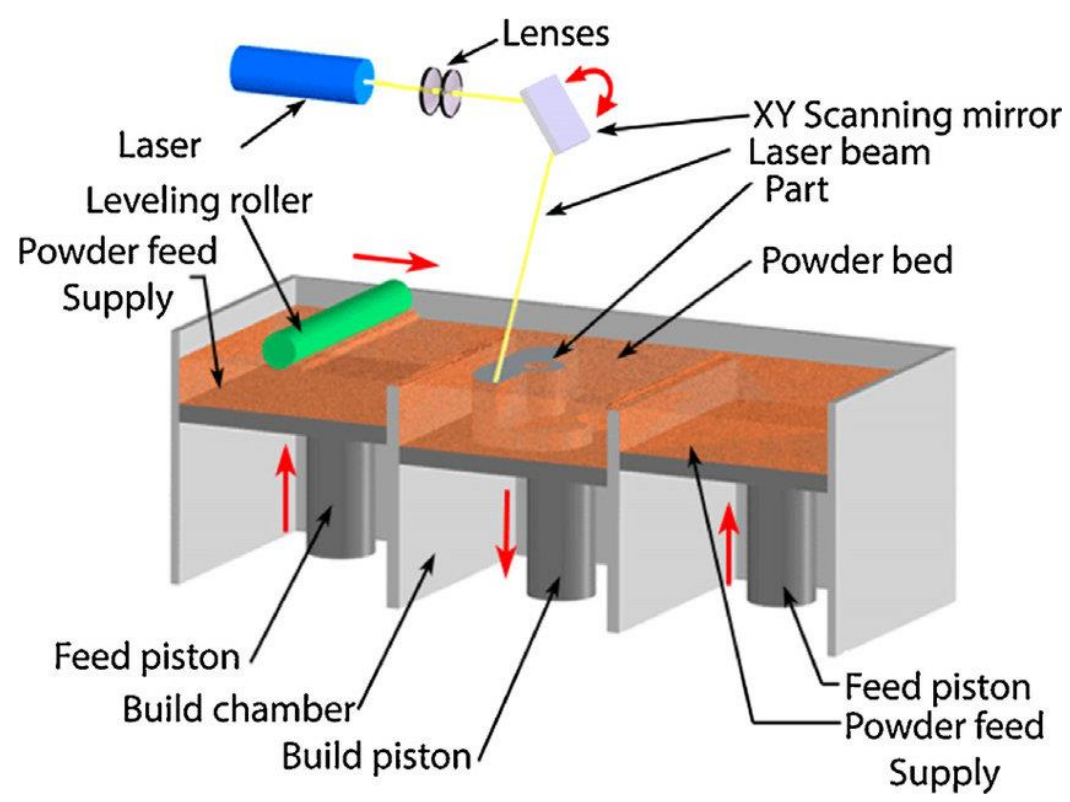

Figure 5. Schematic representation of additive manufacturing techniques [133]. 
Table 3 presents some HEAs fabricated using the AM route. The AlCrFeCoNi HEA system has also been synthesized by Kuwabara et al. [134] and Fujieda et al. [135] using the selective electron beam melting (SEBM) AM technique. The microstructure of the SEBM HEA exhibited a BCC and a B2 phase, same as that reported when processed through the melting and casting route, despite the rapid solidification of the SEBM process $[16,28]$. In addition to the BCC microstructure, an FCC phase was observed at the bottom of the SEBM-fabricated HEA. The precipitation of the FCC phase could have resulted from the $\mathrm{BCC}$ or $\mathrm{B} 2$ phase in a lower temperature range during building. Moreover, the phase evolution could have also occurred during the preheating process, which is associated with the SEBM AM technology. The coexistence of BCC and FCC phases in AlCrFeCoNi was confirmed when Ji et al. [112] fabricated the same HEA using the powder metallurgy (MA + SPS) approach.

Jung et al. [136] fabricated an $\mathrm{AlCrFeCoMnNi} \mathrm{HEA} \mathrm{using} \mathrm{the} \mathrm{laser} \mathrm{powder} \mathrm{bed} \mathrm{fusion}$ (LPBF) process. Again, the microstructure revealed B2 (Ni-Al-rich) and BCC (Fe-Cr-rich) solid solutions. This is in contrast with the formation of BCC and FCC phases achieved in the same alloy when synthesized using either powder metallurgy or the melting and casting process $[60,118]$. The microstructure formation of the $\mathrm{AlCrFeCoMnNi} \mathrm{HEA} \mathrm{fabricated} \mathrm{by}$ LPBF was attributed to (1) liquid-phase spinodal decomposition from an undercooled melting, (2) the cubic nature of the HEA and the highly textured microstructure associated with LPBF, and (3) properties of alloying elements, such as $\mathrm{Mn}, \mathrm{Al}$, and $\mathrm{Zn}$ volatility at high temperature. Depletion of such elements at the melt pool surface leads to a reduction in the distribution of elemental composition across different layers. For instance, depletion of $\mathrm{Al}$ in the $\mathrm{AlCrFeCoMnNi} \mathrm{HEA}$ results in variation in the $\mathrm{Al}$ content across built layers, which leads to a variation in the phase transition temperatures and the phase composition.

Fine BCC grains were found distributed at the grain boundaries of the FCC matrix when Gao et al. [137] fabricated a CoCrFeMnNi HEA using laser 3D printing technology. This is in contrast with the single-phase FCC achieved by Kucza et al. [14] Tsai, et al. [92], Pickering et al. [11], and Yao et al. [46], who that processed the same HEA using different forms of melting and casting routes. Joo et al. [138] also confirmed the presence of singlephase FCC in $\mathrm{CoCrFeMnNi}$ when fabricated using the powder metallurgy technique. FCC (major) matrix grain boundaries were partially wetted by a BCC solid second phase in the printed HEA. Grain boundary wetting phase transformation is known to be responsible for the morphology of the second solid phase in the grain boundaries of the first solid phase. $\mathrm{Al}_{0.3} \mathrm{CoCrFeNi}$ exhibited single-phase FCC when processed through LPBF [139]. A similar alloy was fabricated using the melting and casting route, yet it showed the same microstructure [47]. However, rapid solidification and anisotropic heat removal associated with LPBF generate fine columnar grains in the HEA. This factor seems to not influence the $\mathrm{Al}_{0.3} \mathrm{CoCrFeNi}$ microstructure in this case. There is consistency in the microstructure of $\mathrm{AlCoCrFeNiTi}_{0.5}$ when fabricated using both laser-engineered net shaping (LENS) [140] as well as the melting and casting route [141]. The microstructure exhibited both disordered and ordered BCC phases. However, Shaofeng et al. [116] reported a mixture of BCC and FCC in the same alloy when fabricated using MA + SPS. A laser-engineered net-shapingprocessed $\mathrm{AlCoCrFeNiTi}{ }_{0.5}$ HEA contains a fully equiaxed grain microstructure rather than a columnar microstructure mostly associated with alloys fabricated by AM [142-144]. Hence, an $\mathrm{AlCoCrFeNiTi}_{0.5}$ HEA defies the norms in this regard. Luo et al. [145] reported a BCC solid solution in a selective laser-melting-processed $\mathrm{AlCrCuFeNi} \mathrm{HEA.} \mathrm{However,}$ Jinhong et al. [73] and Anmin et al. [74] reported the presence of FCC and BCC in the same as-cast alloy. The presence of FCC and BCC phases was also confirmed in the same HEA using the powder metallurgy approach [120]. The FCC phase formation might have been inhibited as a result of rapid cooling during the selective laser melting fabrication process [73]. In this fabrication process, the high lattice distortion and elastic strain induced in the HEA is a result of the rapid cooling. 
Table 3. Phase evolution of HEAs fabricated using different additive manufacturing routes.

\begin{tabular}{|c|c|c|c|c|}
\hline HEA Composition & Processing Method & Observed Phase(s) & Microstructures and Comments & Reference \\
\hline CoCrFeMnNi & Laser 3D printing & $\mathrm{FCC}$ (major) + BCC & $\begin{array}{l}\text { An equiaxed-to-columnar transition structure was discovered } \\
\text { in the melt pool. }\end{array}$ & [137] \\
\hline CoCrFeMnNi & Laser powder bed fusion (LPBF) & $\mathrm{FCC}+\sigma$ phase & $\begin{array}{c}\text { Nanotwins were present in the printed sample. } \\
\text { Mn segregates at the boundary of the weld pool due to } \\
\text { its volatility. }\end{array}$ & [146] \\
\hline $\mathrm{CoCrFeMnNi}$ & Laser directed energy deposition & FCC solid solution & $\begin{array}{l}\text { No phase transformation occurred } \\
\text { Lattice strain and grain refinement occurred. }\end{array}$ & [147] \\
\hline $\mathrm{AlCrFeCoNi}$ & Selective electron beam melting (SEBM) & $\mathrm{FCC}+\mathrm{BCC}$ & Phase evolution occurred during the preheating process & {$[134,135]$} \\
\hline $\mathrm{AlCrFeCoMnNi}$ & LPBF & $\mathrm{BCC}(\mathrm{B} 2, \mathrm{~A} 2)$ & $\begin{array}{c}\text { B2 (Ni-Al rich) and } \mathrm{A} 2(\mathrm{Fe}-\mathrm{Cr} \text { rich) } \\
\text { Due to liquid-phase spinodal decomposition and cubic nature } \\
\text { of the HEA }\end{array}$ & [136] \\
\hline $\mathrm{Al}_{0.3} \mathrm{CoCrFeNi}$ & LPBF & Supersaturated FCC phase & $\begin{array}{l}\text { Fine columnar grains were present due to rapid solidification } \\
\text { and anisotropic heat removal. }\end{array}$ & [139] \\
\hline $\mathrm{AlCoCrFeNiTi}_{0.5}$ & Laser-engineered net shaping (LENS) & $2 \mathrm{BCC}(\mathrm{B} 2, \mathrm{~A} 2)$ & $\begin{array}{l}\text { A fully equiaxed grain microstructure was exhibited rather } \\
\text { than a columnar microstructure associated with alloys } \\
\text { fabricated with AM. }\end{array}$ & [140] \\
\hline $\mathrm{AlCrCuFeNi}$ & LPBF & $2 \mathrm{BCC}(\mathrm{B} 2, \mathrm{~A} 2)$ & $\begin{array}{c}\text { Unique columnar grains were present containing multiple } \\
\text { ultrafine sub-grain structures. }\end{array}$ & [145] \\
\hline $\mathrm{AlCrFeNiV}$ & LPBF & FCC & $\begin{array}{l}\text { Rapid cooling rate and solidification resulted in the formation } \\
\text { of sub-grains in every columnar grain and } \mathrm{L} 1_{2} \text { nano-phase. }\end{array}$ & [148] \\
\hline $\mathrm{AlCrFe}_{2} \mathrm{Ni}_{2}$ & LPBF & $\mathrm{BCC}$ & $\begin{array}{c}\text { Columnar BCC of spinodal decomposed B2 and A2 structures } \\
\text { was exhibited. } \\
\text { Cracks were present at the intergranular site. }\end{array}$ & [149] \\
\hline $\mathrm{FeCoCrNi}$ & LPBF & FCC & $\begin{array}{c}\text { After annealing at } 1373 \mathrm{~K} \text {, columnar grains and equiaxial } \\
\text { grains were found to co-exist. }\end{array}$ & [150] \\
\hline
\end{tabular}


Table 3. Cont.

\begin{tabular}{|c|c|c|c|c|}
\hline HEA Composition & Processing Method & Observed Phase(s) & Microstructures and Comments & Reference \\
\hline $\mathrm{AlCoCrFeNi}$ & Direct laser fabrication (DLF) & $\mathrm{BCC}(\mathrm{B} 2)$ & $\begin{array}{c}\text { Intergranular needle-like and plate-like FCC phase } \\
\text { precipitates and wall-shaped FCC phase precipitates were } \\
\text { present along grain boundaries after aging at } 800,1000, \\
\text { and } 1200^{\circ} \mathrm{C} \text {. }\end{array}$ & [151] \\
\hline MoNbTaW & Direct energy deposition (DED) & BCC & & [152] \\
\hline $\mathrm{Al}_{0.5} \mathrm{Cr}_{1.0} \mathrm{Mo}_{1.0} \mathrm{Nb}_{1.0} \mathrm{Ta}_{0.5}$ & SEBM & $\mathrm{BCC}$ & $\begin{array}{l}\text { Two phases were present: TaMoNbCr and }(\mathrm{TaMoNbCr})_{\mathrm{Al}} \\
\text { solid solutions. }\end{array}$ & [153] \\
\hline $\mathrm{AlCoCrFeNi}_{2.1}$ & LENS & Ordered FCC $\left(\mathrm{L1}_{2}\right)+\mathrm{BCC}$ & $\begin{array}{c}\mathrm{Co}, \mathrm{Cr} \text {, and } \mathrm{Fe} \text { stabilize } \mathrm{L1}_{2} \text {. } \\
\mathrm{L}_{2} \text { and } \mathrm{BCC} \text { are rich in nickel. }\end{array}$ & [156] \\
\hline $\mathrm{Fe}_{38.5} \mathrm{Mn}_{20} \mathrm{Co}_{20} \mathrm{Cr}_{15} \mathrm{Si}_{5} \mathrm{Cu}_{1.5}$ & LPBF & FCC & $\begin{array}{l}\text { Deformation-induced phase transformation of } \gamma(\mathrm{FCC}) \text { to } \varepsilon \\
(\mathrm{HCP}) \text { occurred in the vicinity of microcracks. }\end{array}$ & [157] \\
\hline $\mathrm{CoCrFeNi}$ & 3D extrusion printing & FCC & $\begin{array}{l}\text { There was complex structural evolution, from loosely packed } \\
\text { oxide particles in the green body to fully-annealed, } \\
\text { metallic CoCrFeNi. }\end{array}$ & [158] \\
\hline $\mathrm{AlCrFeMoV}_{\mathrm{x}}(\mathrm{x}=0$ to 1$)$ & LENS & BCC & $\begin{array}{l}\text { The high solubility of } \mathrm{V} \text { offers a broad range of solid solution } \\
\text { strengthening of a compositionally complex but structurally } \\
\text { simple BC matrix. }\end{array}$ & [158] \\
\hline ZrTiVCrFeNi & LENS & $\begin{array}{l}\text { C14 Laves phase (major) }+\alpha-\mathrm{Ti} \\
\text { solid solution }\end{array}$ & $\begin{array}{l}\text { The C14 Laves phase becomes stable on exposure to annealing } \\
\text { and hydrogen influence. }\end{array}$ & [159] \\
\hline 6FeNiCoSiCrAlTi & Laser cladding & $\mathrm{BCC}$ & $\begin{array}{l}\text { Equiaxed polygonal grains, discontinuous interdendritic } \\
\text { segregation, and nano-precipitates are present. }\end{array}$ & [160] \\
\hline
\end{tabular}


Table 3. Cont.

\begin{tabular}{|c|c|c|c|c|}
\hline HEA Composition & Processing Method & Observed Phase(s) & Microstructures and Comments & Reference \\
\hline MoFeCrTiW & Laser cladding & $\mathrm{BCC}$ & $\begin{array}{c}\text { Cellular crystals are formed on which dispersion } \\
\text { precipitates exist. }\end{array}$ & [161] \\
\hline TiZrNbMoV & LENS & $\begin{array}{l}\text { FCC }\left(\delta \mathrm{TiH}_{\mathrm{x}} \text {-type }\right)+\mathrm{BCC} \\
\left(\mathrm{NbH}_{\sim 0.4} \text {-type }\right)\end{array}$ & $\begin{array}{l}\alpha \mathrm{Zr} \text {-rich precipitates are present, in addition to the } \\
\text { phases formed. }\end{array}$ & [162] \\
\hline $\mathrm{Al}_{0.5} \mathrm{FeCu}_{0.7} \mathrm{NiCoCr}$ & Laser cladding & $\mathrm{FCC}+\mathrm{BCC}+\mathrm{Al}$ phases & $\begin{array}{l}\text { A laser rapid cooling rate facilitates the formation of a simple } \\
\text { structure and prohibits the formation of undesired } \\
\text { intermetallic compounds. }\end{array}$ & [163] \\
\hline $\mathrm{Al}_{0.5} \mathrm{CrMoNbTa}_{0.5}$ & Electron beam melting (EBM) & $\mathrm{BCC}$ & Intermetallic phases $\mathrm{C} 14, \mathrm{C} 36, \mathrm{C} 15$, and $6 \mathrm{H}$ are present. & [165] \\
\hline $\mathrm{Ni}_{6} \mathrm{Cr}_{4} \mathrm{WFe}_{9} \mathrm{Ti}$ & LPBF & FCC & Tiny precipitates of an unknown phase are present. & [166] \\
\hline $\mathrm{FeCoCrNiC}_{0.05}$ & LPBF & FCC & $\begin{array}{c}\text { Nano-scale } \mathrm{Cr}_{23} \mathrm{C}_{6} \text {-type carbides can precipitate under } \\
\text { annealing conditions. }\end{array}$ & [167] \\
\hline
\end{tabular}




\section{Mechanical Properties}

The strengthening effect in a traditional solid solution is achieved as a result of the mismatch between solute and solvent causing a strain field in the alloy [168]. Some scholars believe it is difficult to differentiate between solvent and solute in HEAs due to their equal or near-equal chemical compositions [169]. Therefore, it is a challenge to evaluate the strengthening effect by applying traditional solid-solution-strengthening mechanisms to HEAs. Researchers have come up with several mechanistic theories to predict the plastic yield strength, especially in FCC HEAs. Labusch-type models of Varvenne, Luque, and Curtin are some of these parameter-free theories $[170,171]$. They predict the plastic yield strength of FCC HEAs as a function of temperature, composition, and strain. The successful application of conventional or traditional strengthening methods on HEAs results in a reduction in toughness [172]. The strengthening mechanisms in HEAs can be summarized as solid solution hardening $\left(\sigma_{\mathrm{s}}\right)$, precipitation hardening $\left(\sigma_{\mathrm{d}}\right)$, grain boundary strengthening $\left(\sigma_{\mathrm{g}}\right)$, and dislocation hardening $\left(\sigma_{\mathrm{p}}\right)$. Hence, the yield strength of an HEA can be expressed as the summation of every individual contribution [170].

$$
\sigma_{0.2}=\sigma_{0}+\Delta \sigma_{\mathrm{s}}+\Delta \sigma_{\mathrm{d}}+\Delta \sigma_{\mathrm{g}}+\Delta \sigma_{\mathrm{p}}
$$

where $\sigma_{0}$ is the yield strength of the alloy, which is the intrinsic strength, or lattice friction strength.

\subsection{Solid Solution Hardening}

Defining or evaluating the contribution of solid-state strengthening in HEAs remains a challenge. This implies that the mechanism of hardening is not yet well understood. Any attempt to apply traditional solid-solution-hardening theories to HEAs proves abortive. For instance, the yield strength value realized in the $\mathrm{FeCoNiCr}$ solvent matrix containing the $\mathrm{Ti}+\mathrm{Al}$ solute is too small to account for the strength difference in the HEA [173]. Hence, it can be assumed that solid solution hardening is not the dominant mechanism in this process. According to Senkov et al. [39], the high hardness (5.25 GPa) attained in the high-entropy BCC-phase $\mathrm{WNbMoTaV}$ alloy cannot be attributed to solid solution hardening. Some researchers believe that solid solution hardening is the main cause of the exceptional mechanical properties of HEAs.

\subsection{Precipitation Hardening}

Precipitation strengthening is another way by which HEAs have been strengthened, and modes of strengthening are categorized based on different interaction mechanisms [174]. For instance, (1) stacking-fault strengthening, (2) modulus strengthening, and (3) chemical strengthening are grouped among modes of precipitation hardening when dislocation cuts through particles $[175,176]$. Less attention is given to the above-mentioned modes of precipitation strengthening since they contribute much less to the yield strength in HEAs. Other modes of precipitation hardening are coherency strengthening and ordering strengthening [177]. Other modes of precipitation hardening have also been used to strengthen HEAs, especially FCC HEAs. Here, fine precipitates are expected to generate hardening either through a particle-shearing mechanism or through a dislocation bypass mechanism (Orowan type). The shearing mechanism occurs when precipitates are sufficiently small and coherent [177]. However, in the Orowan mechanism, the radius of particles is incoherent with the matrix or the particles are not easy to cut through; hence, hardening exceeds a critical value [178]. Ashby-Orowan predicted the yield strength caused by the Orowan mechanism through the relation below [179]:

$$
\Delta \sigma_{\text {orowan }}=0.538 \mathrm{G} b f^{\frac{1}{2}} / \mathrm{r} \times \ln (\mathrm{r} / 2 b)
$$


In some HEAs, yield strength has been successfully enhanced by improving the volume fraction of coherent $\gamma^{\prime}$ phase through an increase in the $\mathrm{Al}$ and Ti concentrations $[168,180,181]$. In superalloys, the $\gamma^{\prime \prime}$ phase as a precipitate has been demonstrated to have a better strengthening effect than $\gamma^{\prime}$ due to its higher anti-phase boundary energy and higher lattice misfit [182]. An excellent combination of yield strength (954 MPa) and ductility $(27 \%)$ was realized in an $\mathrm{Ni}_{2} \mathrm{CoCrFeNb}_{0.15}$ HEA by enhancing its yield strength by $670 \mathrm{MPa}$ using the $\gamma^{\prime \prime}$ precipitate [177]. For the $\gamma^{\prime \prime}$ phase, yield strength has mostly been reported as a result of both coherency and ordering mode of the strengthening mechanism. Equations for coherency and ordering strengthening for the $\gamma^{\prime \prime}$ phase can be found below [183]:

$$
\begin{gathered}
\Delta \sigma_{\text {coherency }}=1.7 \mathrm{MG}|\varepsilon|^{3 / 2} \times\left[\mathrm{h}^{2} f(1-\beta) / 2 b R\right]^{\frac{1}{2}} \\
\Delta \sigma \gamma^{\prime \prime} \text { ordering }=\mathrm{M}(\gamma \mathrm{APB} / 2 b)\{[4 \gamma \mathrm{APB} f / \pi \mathrm{T} \times(\sqrt{ } 6 \mathrm{Rh} / 3)]-\beta f\}
\end{gathered}
$$

where $G$ is shear modulus, $f$ is the volume fraction of precipitates, $\varepsilon$ is the tetragonal lattice of misfit, $b$ is the magnitude of Burger's vector, $h$ is the half-thickness of the particles, $R$ is the real diameter of the particles, $\gamma$ APB is the antiphase boundary energy of the $\gamma^{\prime \prime}$ phase, $\beta$ is a constant and equal to ${ }^{1} / 3$ when all three variants are observed, $T$ is the line tension, and $\mathrm{M}$ is Taylor factor (3.06 for an FCC polycrystalline matrix).

However, aside from difficulties associated with designing $\gamma^{\prime \prime}$ phase(precipitates) for multiphased HEAs, it is also a challenge to precisely measure or control the chemical composition of precipitates. Eißmann et al. [184] demonstrated how the precipitation hardening method was used to increase the Cantor alloy hardness. Precipitation hardening was used to reach the maximum hardness of $353 \mathrm{HV}$ in Ti-6-750-10, exceeding the cantor alloy by a factor of 2 [184]. He et al. [168] attributed the strength increment of about 326.7 MPa achieved in FeCoNiCr HEA to precipitation hardening.

\subsection{Grain Boundary Strengthening}

The smaller the grain size, the higher the volume fraction of grain boundaries, which hinders dislocation motion and thereby improves the strength of HEAs. The relationship between yield strength and grain size is well described by the Hall-Petch equation $[185,186]$ :

$$
\sigma_{\mathrm{y}}=\sigma_{0}+\mathrm{k}_{\mathrm{y}} / \mathrm{d}^{\frac{1}{2}}
$$

where $\sigma_{\mathrm{y}}$ is the yield stress, $\sigma_{0}$ is the lattice friction stress, $\mathrm{d}$ is the average grain diameter, and $\mathrm{k}_{\mathrm{y}}$ is the strengthening coefficient. From Equation (4), an increase in yield strength as a result of grain size difference $\left(\Delta \sigma_{G}\right)$ can be expressed as

$$
\Delta \sigma_{\mathrm{G}}=\mathrm{k}_{\mathrm{y}} \times\left(\mathrm{d}_{\mathrm{p}}{ }^{-\frac{1}{2}}-\mathrm{d}_{\mathrm{A}}{ }^{-\frac{1}{2}}\right)
$$

where $d_{p}$ represents the grain size of the thermomechanically processed materials.

The value of the yield strength increase caused by the grain size difference obtained in FeCoNiCrMn is too small to account for the total strength increase in the HEA [187]. The hardness of $580 \mathrm{HV}$ realized in $\mathrm{CoCrFeNi}$ was attributed to precipitation strengthening and grain boundary strengthening [23]. Liu et al. [188] also attributed the high tensile strength of $712.5 \mathrm{MPa}$, as well as the high elongation of $56 \%$, to grain boundary strengthening in the same alloy. Ganji et al. [189] showed that grain boundary strengthening contributes about $85 \%$ of flow stress in AlCoCrCuFeNi HEA. Strain hardening and grain boundary strengthening were reportedly responsible for the hardness of $8.13 \mathrm{GPa}$ and an elastic modulus of $172 \mathrm{GPa}$ achieved in a dual-phase (FCC + BCC) AlCoCrCuFeNi HEA [189]. 


\subsection{Dislocation Hardening}

Dislocation hardening is caused by interaction between solute atoms of different sizes and properties, resulting in an elastically disorganized crystal lattice. This brings about the formation of a local elastic stress field for an increase in strength to take place. An increase in strength is achieved as a result of interaction between mobile dislocations, as they hinder their own movement. Hence, a higher dislocation density leads to a higher yield strength. The Bailey-Hirsch equation can be applied to describe the relationship [190]:

$$
\Delta \sigma_{\mathrm{D}}=\mathrm{M} \alpha G b \rho^{\frac{1}{2}}
$$

where $\rho$ stands for the dislocation density, $b$ is the burger vector, and $\alpha$ is a constant (e.g., 0.2 for FCC metals).

He et al. [168] demonstrated that a good balance between yield strength and ductility can be achieved in FCC HEAs through good use of grain boundary hardening, dislocation hardening, and precipitation hardening. Studies have also shown that phase transformation can be triggered by small interstitial solutes such as carbon or boron during solid solution strengthening. Research has also proved that boride and carbide compounds precipitate in some HEAs such as $\mathrm{Al}_{0.5} \mathrm{CoCrCuFeNiB}_{\mathrm{x}}$ and $\mathrm{Al}_{0.3} \mathrm{CoCrFeNiC} \mathrm{C}_{0.1}$ when fabricated using arc-melting [191]. However, the presence of an energy barrier stabilizes the interstitial solid solution. Improved mechanical properties were achieved on an $\mathrm{FeCoNiCrCuTiMoAlSiB}{ }_{0.5}$ HEA as a result of an interstitial solute and laser rapid solidification [191]. The presence of an interstitial solute and other factors co-triggered the nucleation of the martensitic phase, which contributed to improved properties in the $\mathrm{FeCoNiCrCuTiMoAlSiB}_{0.5} \mathrm{HEA}$. Table 4 below summarizes different strengthening mechanisms used in improving the mechanical properties of HEAs processed by various fabrication methods and their resulting microstructures as well as the respective phase(s) achieved.

It can be deduced that the synthesis route has little or no influence on the HEA microstructure. This was the case when the noble cantor alloy CoCrFeNiMn maintained an FCC phase when processed through melting and casting [11,46] as well as MA + SPS [192], but the FCC + BCC phase was reported when fabricated via AM technology $[137,146,147]$. $\mathrm{AlCoCrCuFeNi}$ was also fabricated using the melting and casting route [64] as well as the MA + SPS route [189], both resulting in an FCC + BCC phase. The BCC phase was achieved in the same HEA when fabricated via the AM route [154]. Furthermore, it is difficult to evaluate the effect of solid-solution-strengthening mechanisms on HEAs' mechanical properties with respect to the synthesis route and resulting microstructure. This is evident when the hardness achieved in an FCC + BCC AlCoCrCuFeNi HEA processed through the melting and casting route and MA + SPS is recorded as $515.5 \mathrm{HV}$ (5.056 GPa) [64] and $8.13 \mathrm{GPa}$ [189], respectively, while a $\mathrm{Ni}_{1.5} \mathrm{Co}_{1.5} \mathrm{CrFeTi}_{0.5}$ FCC phase HEA processed through the same melting and casting route and MA + SPS reportedly had a hardness of $515 \mathrm{HV}$ [48] and $442 \mathrm{HV} 0.3$ [119], respectively. Hence, greater hardness is achieved in an $\mathrm{AlCoCrCuFeNi} \mathrm{HEA} \mathrm{processed} \mathrm{through} \mathrm{MA} \mathrm{+} \mathrm{SPS} \mathrm{than} \mathrm{when} \mathrm{synthesized} \mathrm{using} \mathrm{the}$ melting and casting method. However, the reverse is the case when a $\mathrm{Ni}_{1.5} \mathrm{Co}_{1.5} \mathrm{CrFeTi}_{0.5}$ HEA is processed through the same set of fabrication methods despite the two HEAs being strengthened by solid solution strengthening and grain boundary strengthening. 
Table 4. Different strengthening mechanisms used to improve the mechanical properties of some HEAs processed by different fabrication methods.

\begin{tabular}{|c|c|c|c|c|c|c|c|c|c|}
\hline \multirow{2}{*}{ HEA Composition } & \multicolumn{3}{|c|}{$\begin{array}{c}\text { Observed Phase(s) through Different } \\
\text { Processing Route(s) }\end{array}$} & \multicolumn{3}{|c|}{ Strengthening Mechanism in Respective Processing Route(s) } & \multicolumn{3}{|c|}{ Effects on Mechanical Properties } \\
\hline & $\begin{array}{l}\text { Melting and } \\
\text { Casting }\end{array}$ & MA + SPS & AM & $\begin{array}{l}\text { Melting and } \\
\text { Casting }\end{array}$ & MA + SPS & AM & $\begin{array}{l}\text { Melting and } \\
\text { Casting }\end{array}$ & MA + SPS & $\mathbf{A M}$ \\
\hline CoCrFeNiMn & FCC $[11,46]$ & FCC [192] & $\begin{array}{l}\text { FCC + BCC } \\
{[137,146,147]}\end{array}$ & & $\begin{array}{l}\text { Solid solution } \\
\text { strengthening }\end{array}$ & $\begin{array}{l}\text { Grain boundary } \\
\text { strengthening }\end{array}$ & & $\begin{array}{c}\text { Compressive } \\
\text { strength of } \\
1987 \mathrm{MPa} \\
\text { Hardness of } 646 \mathrm{HV}\end{array}$ & $\begin{array}{l}\text { Tensile strength o } \\
601 \mathrm{MPa}\end{array}$ \\
\hline $\mathrm{CoCrFeNiAl}_{0.3}$ & FCC $[68,69]$ & $\mathrm{FCC}+\mathrm{BCC}[112]$ & FCC [139] & $\begin{array}{l}\text { Grain boundary } \\
\text { strengthening }\end{array}$ & $\begin{array}{l}\text { Solid solution } \\
\text { strengthening }\end{array}$ & $\begin{array}{l}\text { Dislocation } \\
\text { hardening }\end{array}$ & $\begin{array}{l}\text { UTS of } 528 \mathrm{MPa} \\
\text { YTS of } 275 \mathrm{MPa}\end{array}$ & $\begin{array}{c}\text { Compressive } \\
\text { strength of } \\
1907 \mathrm{MPa} \\
\text { Hardness of } 625 \mathrm{HV}\end{array}$ & $\begin{array}{c}\text { YS of } 730 \mathrm{MPa} \\
\text { UTS of } 896 \mathrm{MPa}\end{array}$ \\
\hline $\mathrm{CoCrFeNi}$ & & $\mathrm{FCC}+\mathrm{Cr}_{7} \mathrm{C}_{3}[23]$ & FCC [150] & & $\begin{array}{l}\text { Grain boundary } \\
\text { strengthening } \\
(470 \mathrm{HV}), \\
\text { precipitation } \\
\text { strengthening }\end{array}$ & & & Hardness of $580 \mathrm{HV}$ & \\
\hline $\mathrm{AlCoCrCuFeNi}$ & $\begin{array}{c}\mathrm{FCC}+\mathrm{BCC} \\
{[64]}\end{array}$ & $\mathrm{FCC}+\mathrm{BCC}[189]$ & BCC [154] & $\begin{array}{l}\text { Solid solution } \\
\text { strengthening }\end{array}$ & $\begin{array}{l}\text { Grain boundary } \\
\text { strengthening, } \\
\text { solid solution } \\
\text { strengthening }\end{array}$ & & $\begin{array}{c}\text { Hardness of } \\
515.5 \mathrm{HV} \\
(5.056 \mathrm{GPa}) \\
\text { Compressive } \\
\text { strength of } 1.82 \mathrm{GPa}\end{array}$ & $\begin{array}{c}\text { Hardness of } \\
8.13 \mathrm{GPa} \\
\text { Elastic modulus of } \\
172 \mathrm{GPa}\end{array}$ & \\
\hline $\mathrm{TiZrNbMo}_{0.3} \mathrm{~V}_{0.3}$ & BCC [193] & & $\begin{array}{c}\mathrm{FCC}+\mathrm{BCC} \\
{[162]}\end{array}$ & $\begin{array}{l}\text { Solid solution } \\
\text { strengthening }\end{array}$ & & & $\begin{array}{l}\text { Yield strength of } \\
1312 \mathrm{MPa} \text { and } 50 \% \\
\text { increase in } \\
\text { plastic strain }\end{array}$ & & \\
\hline \multirow{3}{*}{$\mathrm{Ni}_{1.5} \mathrm{Co}_{1.5} \mathrm{CrFeTi}_{0.5}$} & \multirow{3}{*}{ FCC $[48]$} & \multirow{3}{*}{ FCC [119] } & & \multirow{3}{*}{$\begin{array}{l}\text { Solid solution } \\
\text { hardening }\end{array}$} & \multirow{3}{*}{$\begin{array}{l}\text { Grain boundary } \\
\text { strengthening }\end{array}$} & & YS of $896 \mathrm{MPa}$ & $\begin{array}{l}\text { Hardness of } \\
442 \text { HV0.3 }\end{array}$ & \\
\hline & & & & & & & $\begin{array}{l}\text { Compressive } \\
\text { strength of } \\
1502 \mathrm{MPa}\end{array}$ & $\begin{array}{c}\text { Tensile strength of } \\
1384 \mathrm{MPa}\end{array}$ & \\
\hline & & & & & & & Hardness of $515 \mathrm{HV}$ & $\begin{array}{l}\text { Elastic modulus of } \\
216 \mathrm{GPa}\end{array}$ & \\
\hline
\end{tabular}


Table 4. Cont.

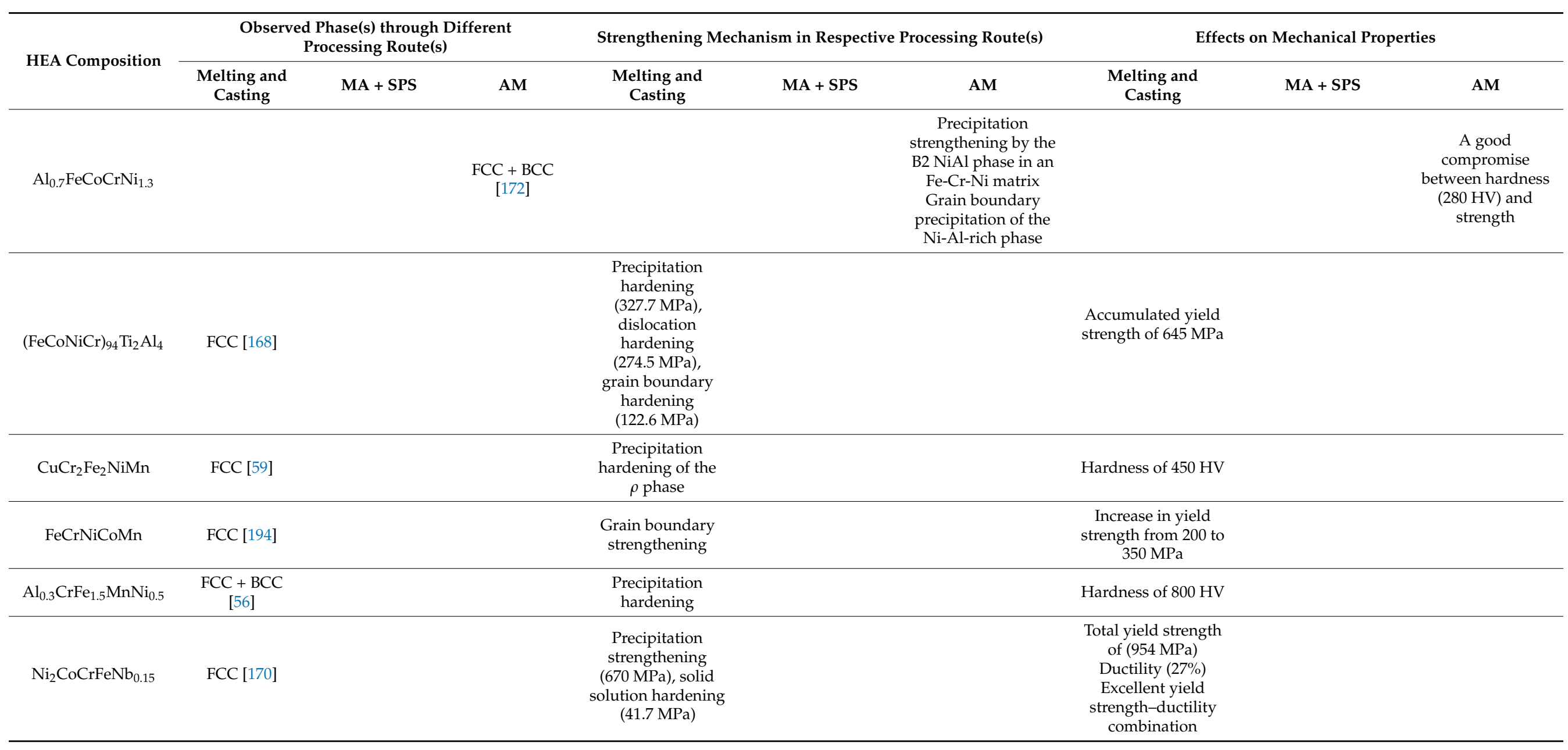


Table 4. Cont.

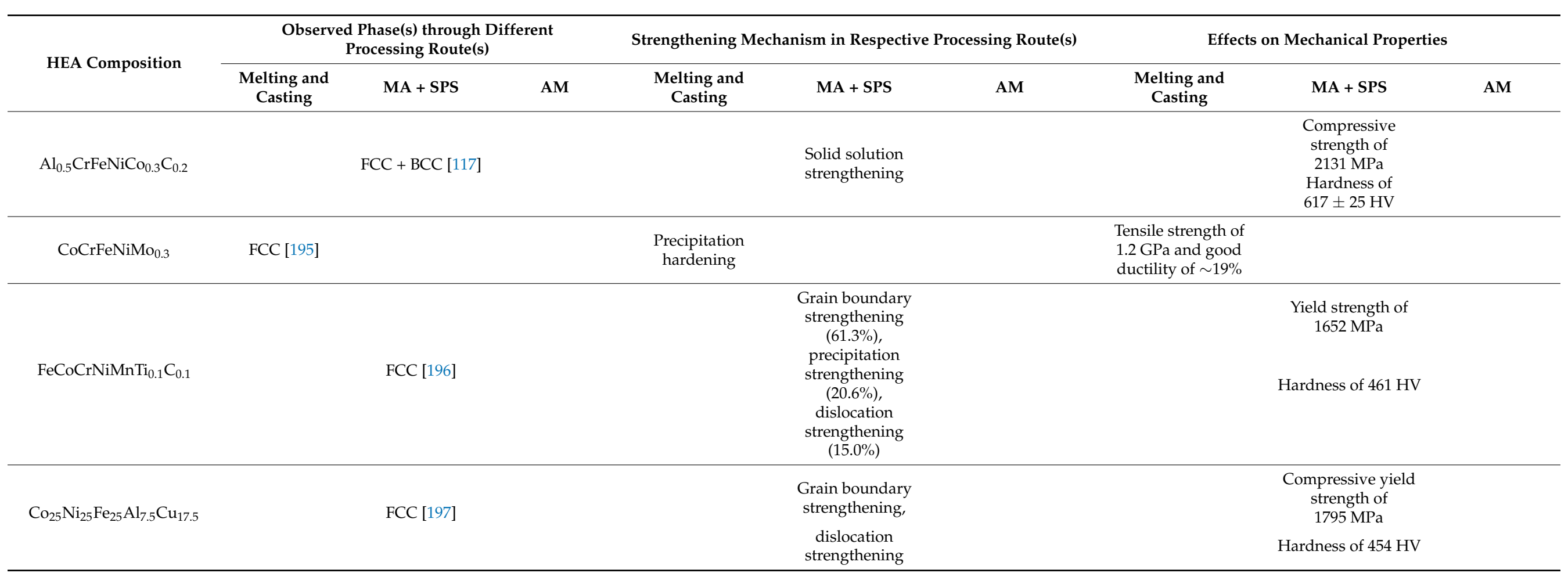




\section{Concluding Remarks}

The quest to achieve specific mechanical properties in HEA systems to meet demands in engineering applications has attracted the attention of researchers over the past decade. This calls for a need to review the processing-structure relationship in HEAs to help in predicting resulting properties. This paper reviewed the relationship between the common processing routes (melting and casting, PM, and AM) and possible structure(s) formed, as well as factors that may influence the properties. The content of this paper can be summarized as follows.

During the melting and casting process, the phase transformation of HEAs occurs during solidification (cooling). During solidification, phase evolution depends on the collective mobility or distribution of constituent elements making up the alloy. However, the rate of cooling, differences in the local atomic arrangement, and the varying elemental diffusivity can influence the solid phase that is first to form and the microstructure of the alloys. HEAs fabricated using the melting and casting route usually show dendritic microstructures with interdendritic segregations. Thus, melting and casting techniques with faster cooling rates favor the formation of a more dominant single phase and limit the precipitation of secondary phases. From another perspective, HEA phase formation during fabrication via the melting and casting route is dependent more on binary constituent pairs than individual constituent elements.

The energy involved during the MA process generates heat and influences the phases that form. Severe plastic deformation generated during the MA process leads to an increase in dislocation density, and lattice strain is introduced into the system. The milling duration/speed, ball-to-powder ratio (BPR), and grinding media contribute to the phase evolution in the powders. The initial structure of binary alloy pairs, sequential addition of individual elements, and order of mixing constituents are some of the factors that also influence the phase evolution. Lattice distortion and sluggish diffusion of elements during the SPS process do influence phase evolution in HEAs. It can also be deduced that the microstructure and phases achieved in the final sintered HEAs can be significantly influenced by the processing parameters used during MA and SPS processes.

In AM technology, some elements such as $\mathrm{Mn}, \mathrm{Al}$, and $\mathrm{Zn}$ mainly deplete at the main melt pool surface at high temperatures due to their high vapor pressure. This leads to a reduction in the distribution of elemental composition across different layers. Variation in the composition across layers results in compositional inhomogeneities in HEAs. For sensitive HEAs, changes in compositions have been seen to have a strong impact on the as-built microstructure. In particular, variation in the $\mathrm{Al}$ content across built layers leads to variation in phase transition temperatures and the phase composition. In addition, solidification mainly takes place along the building direction and is predominantly epitaxial. The successive building process in thin layers by local heat input does characterize the microstructures as a result of rapid and directional solidification. Factors such as powder flowability, laser power, powder thickness and shape, scan spacing, and volumetric energy density (VED) all play an important role in determining the resulting microstructure in AM technology.

\section{Recommendations for Future Studies}

Large differences in the melting temperatures of the constituent elements due to compositional complexity result in elemental segregation, dendritic structure, and residual stress in HEAs fabricated using the melting and casting route. These have a direct impact on the properties of the materials produced to date and could explain some of the discrepancies found within the same-composition alloys produced through the melting and casting route. To address these discrepancies, the rate of cooling, differences in the local atomic arrangement, and the varying elemental diffusivity must be taken into consideration in future studies. Faster cooling routes such as suction casting, injection casting, melt spinning, or splat cooling suppress the precipitation of the secondary phase and thereby 
form a predominantly stable single-phase structure. Hence, induction remelting can reduce microsegregation, reduce the inhomogeneity challenge, and refine the grain size.

Most of the studies on HEAs fabricated by MA are focused on varying the milling duration in achieving a homogeneous solid solution of the elements. However, since the parameters of the MA process are not independent of each other, it is imperative to know that other parameters such as milling speed, the BPR, grinding media, and the milling environment are given some attention in future studies. These other parameters also significantly influence the heat generated during milling and the diffusion of elements in the solid solution process. A lower sintering temperature (depends on the melting temperatures of constituent elements) should also be considered.

There is no adequate information to better understand how, where, and why voids and porosity were formed in most AM-fabricated materials. More attention is needed in this area as controlling their distribution or avoiding them is crucial and requires a better understanding; hence, these defects are undesirable in certain engineering applications. As with all AM technologies, there remains an ongoing quest to reduce cost, improve speed, and improve robustness. However, process validation remains an issue as the quality of the printed material is still in check. Therefore, there is a need for the development and standardization of economically viable and printable materials for engineering applications in the AM fabrication technique spectrum to complement its processing advantages. Urgent attention is needed in developing computer-aided design tools and predictive models of both the printing process and the post-printing material properties in future studies.

Although Li et al. [198], Borkar et al. [199], Welk et al. [200], and more researchers have used the combinatorial approach in processing multicomponent alloys, more attention is still needed on this method owing to the possibility of exploring composition space. This will allow the measurement of a variety of properties across the composition array. Thus, observations suggest that proper selection of the chemical composition and an appropriate processing route combined with appropriate thermomechanical treatment may offer an opportunity to manipulate the strengthening mechanism to enhance HEAs' mechanical properties. An optimal composition with required properties could be more efficient. Their microstructure and properties can be effectively examined. For instance, the lattice distortion that simultaneously emanates from the presence of solutes needs to be measured. Hence, the effect caused by the distortion on dislocation movement is not clear and needs to be understood. In addition, diffusion data and models are critical to understanding the microstructural evolution of HEAs for easy prediction of practical features such as grain growth, growth of strengthening phases, and nucleation. Therefore, more research with modeling and simulations is required, in addition to computational tools and integrated computational material engineering available.

Author Contributions: Conceptualization, writing—original draft preparation, O.T.O.; writingreview and editing, visualization, O.T.O., P.V.C., R.A.N., and W.R.M.; supervision, W.R.M. All authors have read and agreed to the published version of the manuscript.

Funding: This research received no external funding, and the APC was funded by the Vaal University of Technology (South Africa).

Institutional Review Board Statement: Not applicable.

Informed Consent Statement: Not applicable.

Data Availability Statement: The data presented in this study are available on request from the corresponding author.

Acknowledgments: The authors would like to thank and acknowledge the DSI-funded Titanium Centre of Competence ( $\mathrm{TiCoC}$ ), South Africa, for financial support.

Conflicts of Interest: The authors declare no conflict of interest. 


\section{References}

1. Yeh, J.-W.; Chen, S.-K.; Lin, S.-J.; Gan, J.-Y.; Chin, T.-S.; Shun, T.-T.; Tsau, C.-H.; Chang, S.-Y. Nanostructured High-Entropy Alloys with Multiple Principal Elements: Novel Alloy Design Concepts and Outcomes. Adv. Eng. Mater. 2004, 6, 299-303. [CrossRef]

2. Miracle, D.B.; Senkov, O.N. A critical review of high entropy alloys and related concepts. Acta Mater. 2017, 122, 448-511. [CrossRef]

3. Li, Z.; Zhao, S.; Ritchie, R.O.; Meyers, M.A. Mechanical properties of high-entropy alloys with emphasis on face-centered cubic alloys. Prog. Mater. Sci. 2019, 102, 296-345. [CrossRef]

4. Murty, B.S.; Yeh, J.W.; Ranganathan, S.; Bhattacharjee, P.P. 1-A brief history of alloys and the birth of high-entropy alloys. In HighEntropy Alloys, 2nd ed.; Murty, B.S., Yeh, J.W., Ranganathan, S., Bhattacharjee, P.P., Eds.; Elsevier: Amsterdam, The Netherlands, 2019; pp. 1-12.

5. Poletti, M.G.; McCaughey, C.M.; Fiore, G.; Goodall, R.; Battezzati, L. Refractory high entropy alloys: CrMoNbTiVWZr and AlxCryNbMoTiVzZry $(x=0,0.6 ; \mathrm{y}=0.3, \mathrm{z}=0,0.6)$. Int. J. Refract. Met. Hard Mater. 2018, 76, 128-133. [CrossRef]

6. Wu, D.; Kusada, K.; Yamamoto, T.; Toriyama, T.; Matsumura, S.; Kawaguchi, S.; Kubota, Y.; Kitagawa, H. Platinum-Group-Metal High-Entropy-Alloy Nanoparticles. J. Am. Chem. Soc. 2020, 142, 13833-13838. [CrossRef] [PubMed]

7. Feng, R.; Gao, M.C.; Zhang, C.; Guo, W.; Poplawsky, J.D.; Zhang, F.; Hawk, J.A.; Neuefeind, J.C.; Ren, Y.; Liaw, P.K. Phase stability and transformation in a light-weight high-entropy alloy. Acta Mater. 2018, 146, 280-293. [CrossRef]

8. Tseng, K.-K.; Yang, Y.; Juan, C.; Chin, T.; Tsai, C.; Yeh, J.-W. A light-weight high-entropy alloy Al20Be20Fe10Si15Ti35. Sci. China Technol. Sci. 2017, 61. [CrossRef]

9. Santodonato, L.J.; Zhang, Y.; Feygenson, M.; Parish, C.M.; Gao, M.C.; Weber, R.J.; Neuefeind, J.C.; Tang, Z.; Liaw, P.K. Deviation from high-entropy configurations in the atomic distributions of a multi-principal-element alloy. Nat. Commun. 2015, 6, 5964. [CrossRef]

10. Vintila, R.; Charest, A.; Drew, R.; Brochu, M. Synthesis and consolidation via spark plasma sintering of nanostructured Al5356/B4C composite. Mater. Sci. Eng. A 2011, 528, 4395-4407. [CrossRef]

11. Pickering, E.J.; Muñoz-Moreno, R.; Stone, H.J.; Jones, N.G. Precipitation in the equiatomic high-entropy alloy CrMnFeCoNi. Scr. Mater. 2016, 113, 106-109. [CrossRef]

12. Zhang, Y.; Zhou, Y.J.; Lin, J.P.; Chen, G.L.; Liaw, P.K. Solid-Solution Phase Formation Rules for Multi-component Alloys. Adv. Eng. Mater. 2008, 10, 534-538. [CrossRef]

13. Tian, F.; Varga, L.K.; Chen, N.; Shen, J.; Vitos, L. Empirical design of single phase high-entropy alloys with high hardness. Intermetallics 2015, 58, 1-6. [CrossRef]

14. Kucza, W.; Dabrowa, J.; Cieślak, G.; Berent, K.; Kulik, T.; Danielewski, M. Studies of "sluggish diffusion" effect in Co-Cr-Fe-Mn-Ni, Co-Cr-Fe-Ni and Co-Fe-Mn-Ni high entropy alloys; determination of tracer diffusivities by combinatorial approach. J. Alloy. Compd. 2018, 731, 920-928. [CrossRef]

15. Zou, Y.; Maiti, S.; Steurer, W.; Spolenak, R. Size-dependent plasticity in an Nb25Mo25Ta25W25 refractory high-entropy alloy. Acta Mater. 2014, 65, 85-97. [CrossRef]

16. Zhang, K.; Wang, H. Effects of Annealing Treatment on Phase Composition and Microstructure of CoCrFeNiTiAlx High-Entropy Alloys. Intermetallics 2012, 22, 24-32. [CrossRef]

17. Kao, Y.-F.; Chen, T.-J.; Lee, P.-H.; Yeh, J.-W. Microstructure and Mechanical Property of As-Cast, Homogenized, and Deformed AlxCoCrFeNi $(0 \leq \mathrm{x} \leq 2)$ High-Entropy Alloys. J. Alloys Compd. 2009, 488, 57-64. [CrossRef]

18. Li, C.; Li, J.; Zhao, M.; Jiang, Q. Effect of alloying elements on microstructure and properties of multiprincipal elements high-entropy alloys. J. Alloys Compd. 2009, 475, 752-757. [CrossRef]

19. George, E.P.; Raabe, D.; Ritchie, R.O. High-entropy alloys. Nat. Rev. Mater. 2019, 4, 515-534. [CrossRef]

20. Yeh, J.-W. Alloy Design Strategies and Future Trends in High-Entropy Alloys. JOM 2013, 65. [CrossRef]

21. Ye, Y.; Wang, Q.; Lu, J.; Liu, C.; Yang, Y. High-entropy alloy: Challenges and prospects. Mater. Today 2016, 19, 349-362. [CrossRef]

22. Kottke, J.; Laurent-Brocq, M.; Fareed, A.; Gaertner, D.; Perrière, L.; Rogal, Ł.; Divinski, S.V.; Wilde, G. Tracer diffusion in the $\mathrm{Ni}-\mathrm{CoCrFeMn}$ system: Transition from a dilute solid solution to a high entropy alloy. Scr. Mater. 2019, 159, 94-98. [CrossRef]

23. Sathiyamoorthi, P.; Basu, J.; Kashyap, S.; Pradeep, K.; Kottada, R.S. Thermal stability and grain boundary strengthening in ultrafine-grained CoCrFeNi high entropy alloy composite. Mater. Des. 2017, 134, 426-433. [CrossRef]

24. Khan, I.; Mostafa, A.; Aljarrah, M.; Essadiqi, E.; Medraj, M. Influence of cooling rate on microsegregation behavior of magnesium alloys. J. Mater. 2014, 2014, 657647. [CrossRef]

25. Ghiaasiaan, R.; Zeng, X.; Shankar, S. Controlled Diffusion Solidification (CDS) of Al-Zn-Mg-Cu (7050): Microstructure, heat treatment and mechanical properties. Mater. Sci. Eng. A 2014, 594, 260-277. [CrossRef]

26. Manzoni, A.; Daoud, H.; Völkl, R.; Glatzel, U.; Wanderka, N. Phase separation in equiatomic AlCoCrFeNi high-entropy alloy. Ultramicroscopy 2013, 132, 212-215. [CrossRef]

27. Wang, F.J.; Zhang, Y. Effect of Co addition on crystal structure and mechanical properties of Ti0.5CrFeNiAlCo high entropy alloy. Mater. Sci. Eng. A 2008, 496, 214-216. [CrossRef]

28. Tian, Q.; Zhang, G.; Yin, K.; Wang, W.; Cheng, W.; Wang, Y. The strengthening effects of relatively lightweight AlCoCrFeNi high entropy alloy. Mater. Charact. 2019, 151, 302-309. [CrossRef] 
29. Lv, Y.; Hu, R.; Yao, Z.; Chen, J.; Xu, D.; Liu, Y.; Fan, X. Cooling rate effect on microstructure and mechanical properties of AlxCoCrFeNi high entropy alloys. Mater. Des. 2017, 132, 392-399. [CrossRef]

30. Verma, A.; Kumar, S.; Grant, P.; O'Reilly, K. Influence of cooling rate on the Fe intermetallic formation in an AA6063 Al alloy. J. Alloy. Compd. 2013, 555, 274-282. [CrossRef]

31. Wang, F.; Zhang, Y.; Chen, G.; Davies, H. Cooling rate and size effect on the microstructure and mechanical properties of AlCoCrFeNi high entropy alloy. J. Eng. Mater. Technol. 2009, 131, 034501. [CrossRef]

32. Koziel, T. Estimation of cooling rates in suction casting and copper-mould casting processes. Arch. Metall. Mater. 2015, 60, 767-771. [CrossRef]

33. Qiu, Y.; Hu, Y.; Taylor, A.; Styles, M.; Marceau, R.; Ceguerra, A.; Gibson, M.; Liu, Z.; Fraser, H.; Birbilis, N. A lightweight single-phase AlTiVCr compositionally complex alloy. Acta Mater. 2017, 123, 115-124. [CrossRef]

34. Wang, X.; Xie, H.; Jia, L.; Lu, Z.L. Effect of Ti, Al and Cu Addition on Structural Evolution and Phase Constitution of FeCoNi System Equimolar Alloys. Mater. Sci. Forum 2012, 724, 335-338. [CrossRef]

35. Sobol', O.; Andreev, A.; Gorban', V.; Krapivka, N.; Stolbovoi, V.; Serdyuk, I.; Fil'chikov, V. Reproducibility of the single-phase structural state of the multielement high-entropy Ti-V-Zr-Nb-Hf system and related superhard nitrides formed by the vacuum-arc method. Tech. Phys. Lett. 2012, 38, 616-619. [CrossRef]

36. Dong, Y.; Jiang, L.; Jiang, H.; Lu, Y.; Wang, T.; Li, T. Effects of annealing treatment on microstructure and hardness of bulk AlCrFeNiMo0.2 eutectic high-entropy alloy. Mater. Des. 2015, 82, 91-97. [CrossRef]

37. Liu, C.M.; Wang, H.M.; Zhang, S.Q.; Tang, H.B.; Zhang, A.L. Microstructure and oxidation behavior of new refractory high entropy alloys. J. Alloy. Compd. 2014, 583, 162-169. [CrossRef]

38. Zhang, Y.; Zuo, T.; Cheng, Y.; Liaw, P.K. High-entropy Alloys with High Saturation Magnetization, Electrical Resistivity and Malleability. Sci. Rep. 2013, 3, 1455. [CrossRef]

39. Senkov, O.N.; Wilks, G.B.; Miracle, D.B.; Chuang, C.P.; Liaw, P.K. Refractory high-entropy alloys. Intermetallics 2010, 18, 1758-1765. [CrossRef]

40. Senkov, O.N.; Wilks, G.; Scott, J.; Miracle, D.B. Mechanical properties of Nb25Mo25Ta25W25 and V20Nb20Mo20Ta20W20 refractory high entropy alloys. Intermetallics 2011, 19, 698-706. [CrossRef]

41. Tsai, M.-H.; Tsai, K.-Y.; Tsai, C.-W.; Lee, C.; Juan, C.-C.; Yeh, J.-W. Criterion for sigma phase formation in Cr-and V-containing high-entropy alloys. Mater. Res. Lett. 2013, 1, 207-212. [CrossRef]

42. Shaysultanov, D.G.; Salishchev, G.A.; Ivanisenko, Y.V.; Zherebtsov, S.V.; Tikhonovsky, M.A.; Stepanov, N.D. Novel Fe36Mn21Cr18Ni15Al10 high entropy alloy with bcc/B2 dual-phase structure. J. Alloys Compd. 2017, 705, 756-763. [CrossRef]

43. Cui, H.B.; Zheng, L.F.; Wang, J.Y. Microstructure Evolution and Corrosion Behavior of Directionally Solidified FeCoNiCrCu High Entropy Alloy. Appl. Mech. Mater. 2011, 66-68, 146-149. [CrossRef]

44. Ma, Y.; Liu, X.; Dong, W.; Li, R.; Zhang, Y.; Lu, Y.; Yu, P.; Li, G. Interstitial carbide synergistically strengthening high-entropy alloy CoCrFeNiV0.5Cx. Mater. Sci. Eng. A 2020, 792, 139802. [CrossRef]

45. Deng, Y.; Tasan, C.C.; Pradeep, K.G.; Springer, H.; Kostka, A.; Raabe, D. Design of a twinning-induced plasticity high entropy alloy. Acta Mater. 2015, 94, 124-133. [CrossRef]

46. Yao, M.J.; Pradeep, K.G.; Tasan, C.C.; Raabe, D. A novel, single phase, non-equiatomic FeMnNiCoCr high-entropy alloy with exceptional phase stability and tensile ductility. Scr. Mater. 2014, 72-73, 5-8. [CrossRef]

47. Tian, F.; Delczeg, L.; Chen, N.; Varga, L.K.; Shen, J.; Vitos, L. Structural stability of NiCoFeCrAl\$ high-entropy alloy from ab initio theory. Phys. Rev. B 2013, 88, 085128. [CrossRef]

48. Shun, T.-T.; Chang, L.-Y.; Shiu, M.-H. Microstructures and mechanical properties of multiprincipal component CoCrFeNiTix alloys. Mater. Sci. Eng. A 2012, 556, 170-174. [CrossRef]

49. Li, B.-y.; Peng, K.; Hu, A.-p.; Zhou, L.-p.; Zhu, J.-j.; Li, D.-y. Structure and properties of FeCoNiCrCu0.5Alx high-entropy alloy. Trans. Nonferrous Met. Soc. China 2013, 23, 735-741. [CrossRef]

50. He, F.; Wang, Z.; Niu, S.; Wu, Q.; Li, J.; Wang, J.; Liu, C.T.; Dang, Y. Strengthening the CoCrFeNiNb0.25 high entropy alloy by FCC precipitate. J. Alloys Compd. 2016, 667, 53-57. [CrossRef]

51. Chuang, M.-H.; Tsai, M.-H.; Wang, W.-R.; Lin, S.-J.; Yeh, J.-W. Microstructure and wear behavior of AlxCo1.5CrFeNi1.5Tiy high-entropy alloys. Acta Mater. 2011, 59, 6308-6317. [CrossRef]

52. Chou, Y.L.; Yeh, J.W.; Shih, H.C. The effect of molybdenum on the corrosion behaviour of the high-entropy alloys Co1.5CrFeNi1.5Ti0.5Mox in aqueous environments. Corros. Sci. 2010, 52, 2571-2581. [CrossRef]

53. Law, J.Y.; Moreno-Ramírez, L.M.; Díaz-García, Á.; Martín-Cid, A.; Kobayashi, S.; Kawaguchi, S.; Nakamura, T.; Franco, V. MnFeNiGeSi high-entropy alloy with large magnetocaloric effect. J. Alloys Compd. 2021, 855, 157424. [CrossRef]

54. Masemola, K.; Popoola, P.; Malatji, N. The effect of annealing temperature on the microstructure, mechanical and electrochemical properties of arc-melted AlCrFeMnNi equi-atomic High entropy alloy. J. Mater. Res. Technol. 2020, 9, 5241-5251. [CrossRef]

55. Wu, Q.; Wang, Z.; Zheng, T.; Chen, D.; Yang, Z.; Li, J.; Kai, J.-j.; Wang, J. A casting eutectic high entropy alloy with superior strength-ductility combination. Mater. Lett. 2019, 253, 268-271. [CrossRef]

56. Chen, S.-T.; Tang, W.-Y.; Kuo, Y.-F.; Chen, S.-Y.; Tsau, C.-H.; Shun, T.-T.; Yeh, J.-W. Microstructure and properties of age-hardenable AlxCrFe1.5MnNi0.5 alloys. Mater. Sci. Eng. A 2010, 527, 5818-5825. [CrossRef] 
57. Kao, Y.-F.; Chen, S.-K.; Chen, T.-J.; Chu, P.-C.; Yeh, J.-W.; Lin, S.-J. Electrical, magnetic, and Hall properties of AlxCoCrFeNi high-entropy alloys. J. Alloy. Compd. 2011, 509, 1607-1614. [CrossRef]

58. Ren, B.; Liu, Z.; Li, D.; Shi, L.; Cai, B.; Wang, M. Effect of elemental interaction on microstructure of CuCrFeNiMn high entropy alloy system. J. Alloy. Compd. 2010, 493, 148-153. [CrossRef]

59. Ren, B.; Liu, Z.; Cai, B.; Wang, M.; Shi, L. Aging behavior of a CuCr2Fe2NiMn high-entropy alloy. Mater. Des. 2012, 33, 121-126. [CrossRef]

60. He, J.Y.; Liu, W.H.; Wang, H.; Wu, Y.; Liu, X.J.; Nieh, T.G.; Lu, Z.P. Effects of Al addition on structural evolution and tensile properties of the FeCoNiCrMn high-entropy alloy system. Acta Mater. 2014, 62, 105-113. [CrossRef]

61. Pauzi, S.S.M.; Darham, W.; Ramli, R.; Harun, M.; Talari, M.K. Effect of Zr Addition on Microstructure and Properties of FeCrNiMnCoZr x and Al 0.5 FeCrNiMnCoZr x High Entropy Alloys. Trans. Indian Inst. Met. 2013, 66, 305-308. [CrossRef]

62. Wang, C.W.; Mo, Z.Q.; Tang, J.J. The Study about Microstructure Characterization of AlCoCrTiNiCu_x High Entropy Alloy System with Multi-principal element. Adv. Mater. Res. 2012, 399, 3-7. [CrossRef]

63. Mishra, A.K.; Samal, S.; Biswas, K. Solidification behaviour of Ti-Cu-Fe-Co-Ni high entropy alloys. Trans. Indian Inst. Met. 2012, 65, 725-730. [CrossRef]

64. Zhang, K.B.; Fu, Z.Y.; Zhang, J.Y.; Shi, J.; Wang, W.M.; Wang, H.; Wang, Y.C.; Zhang, Q.J. Annealing on the structure and properties evolution of the CoCrFeNiCuAl high-entropy alloy. J. Alloys Compd. 2010, 502, 295-299. [CrossRef]

65. Wen, L.H.; Kou, H.C.; Li, J.S.; Chang, H.; Xue, X.Y.; Zhou, L. Effect of aging temperature on microstructure and properties of AlCoCrCuFeNi high-entropy alloy. Intermetallics 2009, 17, 266-269. [CrossRef]

66. Aguilar-Hurtado, J.Y.; Vargas-Uscategui, A.; Zambrano-Mera, D.; Palma-Hillerns, R. The effect of boron content on the microstructure and mechanical properties of Fe50-XMn30Co10Cr10BX ( $\mathrm{x}=0,0.3,0.6$ and $1.7 \mathrm{wt} \%)$ multi-component alloys prepared by arc-melting. Mater. Sci. Eng. A 2019, 748, 244-252. [CrossRef]

67. Soare, V.; Mitrica, D.; Constantin, I.; Popescu, G.; Csaki, I.; Tarcolea, M.; Carcea, I. The mechanical and corrosion behaviors of as-cast and re-melted AlCrCuFeMnNi multi-component high-entropy alloy. Metall. Mater. Trans. A 2015, 46, 1468-1473. [CrossRef]

68. Guo, T.; Li, J.; Wang, J.; Wang, W.Y.; Liu, Y.; Luo, X.; Kou, H.; Beaugnon, E. Microstructure and properties of bulk Al0.5CoCrFeNi high-entropy alloy by cold rolling and subsequent annealing. Mater. Sci. Eng. A 2018, 729, 141-148. [CrossRef]

69. Lin, C.-M.; Tsai, H.-L. Evolution of microstructure, hardness, and corrosion properties of high-entropy $\mathrm{Al} 0.5 \mathrm{CoCrFeNi}$ alloy. Intermetallics 2011, 19, 288-294. [CrossRef]

70. McAlpine, S.W.; Logan, J.V.; Short, M.P. Predicting single phase stability and segregation in the NbMoTaTi-(W,V) high entropy alloy system with the vacancy exchange potential. Scr. Mater. 2021, 191, 29-33. [CrossRef]

71. Yi, J.; Tang, S.; Xu, M.; Yang, L.; Wang, L.; Zeng, L. A novel Al0.5CrCuNiV 3d transition metal high-entropy alloy: Phase analysis, microstructure and compressive properties. J. Alloys Compd. 2020, 846, 156466. [CrossRef]

72. Gao, X.; Lu, Y.; Zhang, B.; Liang, N.; Wu, G.; Sha, G.; Liu, J.; Zhao, Y. Microstructural origins of high strength and high ductility in an AlCoCrFeNi2.1 eutectic high-entropy alloy. Acta Mater. 2017, 141, 59-66. [CrossRef]

73. Jinhong, P.; Ye, P.; Hui, Z.; Lu, Z. Microstructure and properties of AlCrFeCuNix $(0.6 \leq \mathrm{x} \leq 1.4)$ high-entropy alloys. Mater. Sci. Eng. A 2012, 534, 228-233. [CrossRef]

74. Anmin, L.; Zhang, X. Thermodynamic analysis of the simple microstructure of AlCrFeNiCu high-entropy alloy with multiprincipal elements. Acta Metall. Sin. 2009, 22, 219-224.

75. Qi, J.; Cheung, A.M.; Poon, S.J. High Entropy Alloys Mined From Binary Phase Diagrams. Sci. Rep. 2019, 9, 15501. [CrossRef]

76. Tsao, T.-K.; Yeh, A.-C. The Thermal Stability and Strength of Highly Alloyed Ni3Al. Mater. Trans. 2015, 56, 1905-1910. [CrossRef]

77. Matusiak, K.; Berent, K.; Marciszko, M.; Cieslak, J. The experimental and theoretical study on influence of Al and Cu contents on phase abundance changes in AlxCuyFeCrNiCo HEA system. J. Alloys Compd. 2019, 790, 837-846. [CrossRef]

78. Aizenshtein, M.; Strumza, E.; Brosh, E.; Hayun, S. Precipitation kinetics, microstructure, and equilibrium state of A2 and B2 phases in multicomponent Al2.75CoCrFeNi alloy. J. Mater. Sci. 2020, 55, 7016-7028. [CrossRef]

79. Leong, Z.; Wróbel, J.S.; Dudarev, S.L.; Goodall, R.; Todd, I.; Nguyen-Manh, D. The Effect of Electronic Structure on the Phases Present in High Entropy Alloys. Sci. Rep. 2017, 7, 39803. [CrossRef] [PubMed]

80. Wang, J.; Shang, S.-L.; Wang, Y.; Mei, Z.-G.; Liang, Y.-F.; Du, Y.; Liu, Z.-K. First-principles calculations of binary Al compounds: Enthalpies of formation and elastic properties. Calphad 2011, 35, 562-573. [CrossRef]

81. Vaidya, M.; Prasad, A.; Parakh, A.; Murty, B. Influence of sequence of elemental addition on phase evolution in nanocrystalline $\mathrm{AlCoCrFeNi}$ : Novel approach to alloy synthesis using mechanical alloying. Mater. Des. 2017, 126, 37-46. [CrossRef]

82. Das, S.K.; Horbach, J.; Voigtmann, T. Structural relaxation in a binary metallic melt: Molecular dynamics computer simulation of undercooled Al 80 Ni 20. Phys. Rev. B 2008, 78, 064208. [CrossRef]

83. Dong, Y.; Jiang, L.; Tang, Z.; Lu, Y.; Li, T. Effect of electromagnetic field on microstructure and properties of bulk AlCrFeNiMo 0.2 high-entropy alloy. J. Mater. Eng. Perform. 2015, 24, 4475-4481. [CrossRef]

84. Zheng, H.; Chen, R.; Qin, G.; Li, X.; Su, Y.; Ding, H.; Guo, J.; Fu, H. Phase separation of AlCoCrFeNi2. 1 eutectic high-entropy alloy during directional solidification and their effect on tensile properties. Intermetallics 2019, 113, 106569. [CrossRef] 
85. Shun, T.-T.; Hung, W.-J. Effects of Cr Content on Microstructure and Mechanical Properties of AlCoCr x FeNi High-Entropy Alloy. Adv. Mater. Sci. Eng. 2018, 2018, 5826467. [CrossRef]

86. Chaudhary, V.; Gwalani, B.; Soni, V.; Ramanujan, R.V.; Banerjee, R. Influence of Cr Substitution and Temperature on Hierarchical Phase Decomposition in the AlCoFeNi High Entropy Alloy. Sci. Rep. 2018, 8, 15578. [CrossRef] [PubMed]

87. Tang, Z.; Gao, M.C.; Diao, H.; Yang, T.; Liu, J.; Zuo, T.; Zhang, Y.; Lu, Z.; Cheng, Y.; Zhang, Y.; et al. Aluminum Alloying Effects on Lattice Types, Microstructures, and Mechanical Behavior of High-Entropy Alloys Systems. JOM 2013, 65, 1848-1858. [CrossRef]

88. Mohanty, A.; Sampreeth, J.K.; Bembalge, O.; Hascoet, J.Y.; Marya, S.; Immanuel, R.J.; Panigrahi, S.K. High temperature oxidation study of direct laser deposited AlXCoCrFeNi (X=0.3,0.7) high entropy alloys. Surf. Coat. Technol. 2019, 380, 125028. [CrossRef]

89. Butler, T.M.; Weaver, M.L. Oxidation behavior of arc melted AlCoCrFeNi multi-component high-entropy alloys. J. Alloy. Compd. 2016, 674, 229-244. [CrossRef]

90. Ferrari, V.; Wolf, W.; Zepon, G.; Coury, F.; Kaufman, M.; Bolfarini, C.; Kiminami, C.; Botta, W. Effect of boron addition on the solidification sequence and microstructure of AlCoCrFeNi alloys. J. Alloys Compd. 2019, 775, 1235-1243. [CrossRef]

91. Guo, L.; Xiao, D.; Wu, W.; Ni, S.; Song, M. Effect of Fe on microstructure, phase evolution and mechanical properties of (AlCoCrFeNi) 100-xFex high entropy alloys processed by spark plasma sintering. Intermetallics 2018, 103, 1-11. [CrossRef]

92. Wang, W.-R.; Wang, W.-L.; Yeh, J.-W. Phases, microstructure and mechanical properties of AlxCoCrFeNi high-entropy alloys at elevated temperatures. J. Alloys Compd. 2014, 589, 143-152. [CrossRef]

93. Rogström, L.; Ullbrand, J.; Almer, J.; Hultman, L.; Jansson, B.; Odén, M. Strain evolution during spinodal decomposition of TiAlN thin films. Thin Solid Film. 2012, 520, 5542-5549. [CrossRef]

94. Tsai, K.Y.; Tsai, M.H.; Yeh, J.W. Sluggish diffusion in Co-Cr-Fe-Mn-Ni high-entropy alloys. Acta Mater. 2013, 61, 4887-4897. [CrossRef]

95. Anand, G.; Goodall, R.; Freeman, C.L. Role of configurational entropy in body-centred cubic or face-centred cubic phase formation in high entropy alloys. Scr. Mater. 2016, 124, 90-94. [CrossRef]

96. Mo, Y.; Tian, Z.; Liu, R.; Hou, Z.; Wang, C. Structural evolution during crystallization of rapidly super-cooled copper melt. J. Non-Cryst. Solids 2015, 421, 14-19. [CrossRef]

97. Zhang, L.; Fan, J.; Liu, D.; Zhang, M.; Yu, P.; Jing, Q.; Ma, M.; Liaw, P.; Li, G.; Liu, R. The microstructural evolution and hardness of the equiatomic CoCrCuFeNi high-entropy alloy in the semi-solid state. J. Alloys Compd. 2018, 745, 75-83. [CrossRef]

98. Qin, G.; Wang, S.; Chen, R.; Gong, X.; Wang, L.; Su, Y.; Guo, J.; Fu, H. Microstructures and mechanical properties of Nb-alloyed CoCrCuFeNi high-entropy alloys. J. Mater. Sci. Technol. 2018, 34, 365-369. [CrossRef]

99. Hsu, C.-Y.; Yeh, J.-W.; Chen, S.-K.; Shun, T.-T. Wear resistance and high-temperature compression strength of Fcc CuCoNiCrAl $0.5 \mathrm{Fe}$ alloy with boron addition. MMTA 2004, 35, 1465-1469. [CrossRef]

100. Gwalani, B.; Choudhuri, D.; Soni, V.; Ren, Y.; Styles, M.; Hwang, J.; Nam, S.; Ryu, H.; Hong, S.H.; Banerjee, R. Cu assisted stabilization and nucleation of L12 precipitates in A10. 3CuFeCrNi2 fcc-based high entropy alloy. Acta Mater. 2017, 129, 170-182. [CrossRef]

101. Gwalani, B.; Gorsse, S.; Soni, V.; Carl, M.; Ley, N.; Smith, J.; Ayyagari, A.V.; Zheng, Y.; Young, M.; Mishra, R.S. Role of copper on L12 precipitation strengthened fcc based high entropy alloy. Materialia 2019, 6, 100282. [CrossRef]

102. Zhou, W.; Fu, L.; Liu, P.; Xu, X.; Chen, B.; Zhu, G.; Wang, X.; Shan, A.; Chen, M. Deformation stimulated precipitation of a single-phase CoCrFeMnNi high entropy alloy. Intermetallics 2017, 85, 90-97. [CrossRef]

103. Mucsi, G. A review on mechanical activation and mechanical alloying in stirred media mill. Chem. Eng. Res. Des. 2019, 148, 460-474. [CrossRef]

104. Hebda, M.; Gądek, S.; Skałoń, M.; Kazior, J. Effect of mechanical alloying and annealing on the sintering behaviour of AstaloyCrL powders with $\mathrm{SiC}$ and carbon addition. J. Therm. Anal. Calorim. 2013, 113, 395-403. [CrossRef]

105. Paraskevas, D.; Vanmeensel, K.; Vleugels, J.; Dewulf, W.; Deng, Y.; Duflou, J.R. Spark plasma sintering as a solid-state recycling technique: The case of aluminum alloy scrap consolidation. Materials 2014, 7, 5664-5687. [CrossRef]

106. Shongwe, M.B.; Ramakokovhu, M.M.; Lethabane, M.L.; Olubambi, P.A. Comparison of spark plasma sintering and hybrid spark plasma sintering of Ni-Fe alloys. In Proceedings of the World Congress on Engineering, San Francisco, CA, USA, 25-27 October 2017.

107. Chakraborty, S.; Das, P.K.; Ghosh, D. SPARK PLASMA SINTERING AND STRUCTURAL PROPERTIES OF ZrB 2 BASED CERAMICS: A REVIEW. Rev. Adv. Mater. Sci. 2016, 44, 182-193.

108. Saheb, N.; Iqbal, Z.; Khalil, A.; Hakeem, A.S.; Al Aqeeli, N.; Laoui, T.; Al-Qutub, A.; Kirchner, R. Spark plasma sintering of metals and metal matrix nanocomposites: A review. J. Nanomater. 2012, 2012, 18. [CrossRef]

109. Zhang, X.K.; Huang, J.C.; Lin, P.H.; Liu, T.Y.; Wu, Y.C.; Li, W.P.; Wang, Y.N.; Liao, Y.C.; Jang, J.S.C. Microstructure and mechanical properties of Tix(AlCrVNb)100-x light weight multi-principal element alloys. J. Alloys Compd. 2020, 831, 154742. [CrossRef]

110. Matizamhuka, W. Spark plasma sintering (SPS)-an advanced sintering technique for structural nanocomposite materials. J. S. Afr. Inst. Min. Metall. 2016, 116, 1171-1180. [CrossRef]

111. Enayati, M.; Mohamed, F. Application of mechanical alloying/milling for synthesis of nanocrystalline and amorphous materials. Int. Mater. Rev. 2014, 59, 394-416. [CrossRef]

112. Ji, W.; Fu, Z.; Wang, W.; Wang, H.; Zhang, J.; Wang, Y.; Zhang, F. Mechanical alloying synthesis and spark plasma sintering consolidation of CoCrFeNiAl high-entropy alloy. J. Alloy. Compd. 2014, 589, 61-66. [CrossRef] 
113. Koch, C.C. Nanocrystalline high-entropy alloys. J. Mater. Res. 2017, 32, 3435-3444. [CrossRef]

114. Chen, W.; Fu, Z.; Fang, S.; Xiao, H.; Zhu, D. Alloying behavior, microstructure and mechanical properties in a $\mathrm{FeNiCrCo}_{0.3} \mathrm{Al}_{0.7}$ high entropy alloy. Mater. Des. 2013, 51, 854-860. [CrossRef]

115. Kumar, A.; Swarnakar, A.K.; Chopkar, M. Phase Evolution and Mechanical Properties of AlCoCrFeNiSix High-Entropy Alloys Synthesized by Mechanical Alloying and Spark Plasma Sintering. J. Mater. Eng. Perform. 2018, 27, 3304-3314. [CrossRef]

116. Shaofeng, Y.; Zhang, Y.; Xing, Y.; Hang, Z. Enhancement of Mechanical Properties and Corrosion Resistance of Ultra-Fine Grain A10. 4FeCrCo1. 5NiTi0. 3 High-Entropy Alloy by MA and SPS Technologies. Mater. Sci. 2019, 25, 259-264.

117. Fang, S.; Chen, W.; Fu, Z. Microstructure and mechanical properties of twinned $\mathrm{Al}_{0.5} \mathrm{CrFeNiCo}_{0.3} \mathrm{C}_{0.2}$ high entropy alloy processed by mechanical alloying and spark plasma sintering. Mater. Des. (1980-2015) 2014, 54, 973-979. [CrossRef]

118. Wang, C.; Ji, W.; Fu, Z. Mechanical alloying and spark plasma sintering of CoCrFeNiMnAl high-entropy alloy. Adv. Powder Technol. 2014, 25, 1334-1338. [CrossRef]

119. Moravcik, I.; Cizek, J.; Zapletal, J.; Kovacova, Z.; Vesely, J.; Minarik, P.; Kitzmantel, M.; Neubauer, E.; Dlouhy, I. Microstructure and mechanical properties of Ni1,5Co1,5CrFeTi0,5 high entropy alloy fabricated by mechanical alloying and spark plasma sintering. Mater. Des. 2017, 119, 141-150. [CrossRef]

120. Yurkova, A.I.; Cherniavsky, V.V.; Bolbut, V.; Krüger, M.; Bogomol, I. Structure formation and mechanical properties of the high-entropy $\mathrm{AlCuNiFeCr}$ alloy prepared by mechanical alloying and spark plasma sintering. J. Alloys Compd. 2019, 786, 139-148. [CrossRef]

121. Pan, J.; Dai, T.; Lu, T.; Ni, X.; Dai, J.; Li, M. Microstructure and mechanical properties of Nb25Mo25Ta25W25 and Ti8Nb23Mo23Ta23W23 high entropy alloys prepared by mechanical alloying and spark plasma sintering. Mater. Sci. Eng. A 2018, 738, 362-366. [CrossRef]

122. Fu, Z.; Chen, W.; Wen, H.; Morgan, S.; Chen, F.; Zheng, B.; Zhou, Y.; Zhang, L.; Lavernia, E.J. Microstructure and mechanical behavior of a novel Co20Ni20Fe20Al20Ti20 alloy fabricated by mechanical alloying and spark plasma sintering. Mater. Sci. Eng. A 2015, 644, 10-16. [CrossRef]

123. Pohan, R.M.; Gwalani, B.; Lee, J.; Alam, T.; Hwang, J.Y.; Ryu, H.J.; Banerjee, R.; Hong, S.H. Microstructures and mechanical properties of mechanically alloyed and spark plasma sintered Al0.3CoCrFeMnNi high entropy alloy. Mater. Chem. Phys. 2018, 210, 62-70. [CrossRef]

124. Yadav, S.; Sarkar, S.; Aggarwal, A.; Kumar, A.; Biswas, K. Wear and mechanical properties of novel $(\mathrm{CuCrFeTiZn})_{100-x} \mathrm{~Pb}{ }_{\mathrm{x}}$ high entropy alloy composite via mechanical alloying and spark plasma sintering. Wear 2018, 410-411, 93-109. [CrossRef]

125. Syed Ghazi, S.; Ravi, K.R. Phase-evolution in high entropy alloys: Role of synthesis route. Intermetallics 2016, 73, 40-42. [CrossRef]

126. Wróbel, J.S.; Nguyen-Manh, D.; Lavrentiev, M.Y.; Muzyk, M.; Dudarev, S.L. Phase stability of ternary fcc and bcc Fe-Cr-Ni alloys. Phys. Rev. B 2015, 91, 024108. [CrossRef]

127. Yang, G.; Park, S.-J. Deformation of single crystals, polycrystalline materials, and thin films: A Review. Materials 2019, 12, 2003. [CrossRef] [PubMed]

128. Praveen, S.; Murty, B.; Kottada, R.S. Phase evolution and densification behavior of nanocrystalline multicomponent high entropy alloys during spark plasma sintering. JOM 2013, 65, 1797-1804. [CrossRef]

129. Ma, Y.; Wang, Q.; Jiang, B.; Li, C.; Hao, J.; Li, X.; Dong, C.; Nieh, T. Controlled formation of coherent cuboidal nanoprecipitates in body-centered cubic high-entropy alloys based on Al2 (Ni, Co, Fe, Cr) 14 compositions. Acta Mater. 2018, 147, 213-225. [CrossRef]

130. Li, C.; Ma, Y.; Hao, J.; Wang, Q.; Pang, S.; Dong, C.; Liaw, P.K. Effect of Ti substitution for Al on the cuboidal nanoprecipitates in $\mathrm{Al}$ 0.7 NiCoFeCr 2 high-entropy alloys. J. Mater. Res. 2018, 33, 3266-3275. [CrossRef]

131. Yurkova, A.; Chernyavsky, V.; Hushchyk, D.; Bilyk, I.; Sergey, N. Nanocrystalline AlNiCoFeCrTi High-Entropy Alloy Resulted from Mechanical Alloying and Annealing. In Proceedings of the 2019 IEEE 9th International Conference Nanomaterials: Applications \& Properties (NAP), Odesa, Ukraine, 15-20 September 2019; pp. 1-4.

132. Zhang, D.; Qiu, D.; Gibson, M.A.; Zheng, Y.; Fraser, H.L.; StJohn, D.H.; Easton, M.A. Additive manufacturing of ultrafine-grained high-strength titanium alloys. Nature 2019, 576, 91-95. [CrossRef]

133. Chen, Q.; Guillemot, G.; Gandin, C.-A.; Bellet, M. Three-dimensional finite element thermomechanical modeling of additive manufacturing by selective laser melting for ceramic materials. Addit. Manuf. 2017, 16, 124-137. [CrossRef]

134. Kuwabara, K.; Shiratori, H.; Fujieda, T.; Yamanaka, K.; Koizumi, Y.; Chiba, A. Mechanical and corrosion properties of AlCoCrFeNi high-entropy alloy fabricated with selective electron beam melting. Addit. Manuf. 2018, 23, 264-271. [CrossRef]

135. Fujieda, T.; Shiratori, H.; Kuwabara, K.; Kato, T.; Yamanaka, K.; Koizumi, Y.; Chiba, A. First demonstration of promising selective electron beam melting method for utilizing high-entropy alloys as engineering materials. Mater. Lett. 2015, 159, 12-15. [CrossRef]

136. Jung, H.Y.; Peter, N.J.; Gärtner, E.; Dehm, G.; Uhlenwinkel, V.; Jägle, E.A. Bulk nanostructured AlCoCrFeMnNi chemically complex alloy synthesized by laser-powder bed fusion. Addit. Manuf. 2020, 35, 101337. [CrossRef]

137. Gao, X.; Lu, Y. Laser 3D printing of CoCrFeMnNi high-entropy alloy. Mater. Lett. 2019, 236, 77-80. [CrossRef]

138. Joo, S.-H.; Kato, H.; Jang, M.; Moon, J.; Tsai, C.; Yeh, J.; Kim, H. Tensile deformation behavior and deformation twinning of an equimolar CoCrFeMnNi high-entropy alloy. Mater. Sci. Eng. A 2017, 689, 122-133. [CrossRef]

139. Peyrouzet, F.; Hachet, D.; Soulas, R.; Navone, C.; Godet, S.; Gorsse, S. Selective Laser Melting of Al0.3CoCrFeNi High-Entropy Alloy: Printability, Microstructure, and Mechanical Properties. JOM 2019, 71, 3443-3451. [CrossRef] 
140. Guan, S.; Solberg, K.; Wan, D.; Berto, F.; Welo, T.; Yue, T.M.; Chan, K.C. Formation of fully equiaxed grain microstructure in additively manufactured AlCoCrFeNiTi0.5 high entropy alloy. Mater. Des. 2019, 184, 108202. [CrossRef]

141. Zhou, Y.; Zhang, Y.; Wang, Y.; Chen, G. Solid solution alloys of Al Co Cr Fe Ni Ti x with excellent room-temperature mechanical properties. Appl. Phys. Lett. 2007, 90, 181904. [CrossRef]

142. Ishimoto, T.; Hagihara, K.; Hisamoto, K.; Sun, S.-H.; Nakano, T. Crystallographic texture control of beta-type Ti-15Mo-5Zr-3Al alloy by selective laser melting for the development of novel implants with a biocompatible low Young's modulus. Scr. Mater. 2017, 132, 34-38. [CrossRef]

143. Dinda, G.; Dasgupta, A.; Mazumder, J. Texture control during laser deposition of nickel-based superalloy. Scr. Mater. 2012, 67, 503-506. [CrossRef]

144. Chauvet, E.; Kontis, P.; Jägle, E.A.; Gault, B.; Raabe, D.; Tassin, C.; Blandin, J.-J.; Dendievel, R.; Vayre, B.; Abed, S. Hot cracking mechanism affecting a non-weldable Ni-based superalloy produced by selective electron Beam Melting. Acta Mater. 2018, 142, 82-94. [CrossRef]

145. Luo, S.; Gao, P.; Yu, H.; Yang, J.; Wang, Z.; Zeng, X. Selective laser melting of an equiatomic AlCrCuFeNi high-entropy alloy: Processability, non-equilibrium microstructure and mechanical behavior. J. Alloys Compd. 2019, 771, 387-397. [CrossRef]

146. Li, R.; Niu, P.; Yuan, T.; Cao, P.; Chen, C.; Zhou, K. Selective laser melting of an equiatomic CoCrFeMnNi high-entropy alloy: Processability, non-equilibrium microstructure and mechanical property. J. Alloys Compd. 2018, 746, 125-134. [CrossRef]

147. Tong, Z.; Liu, H.; Jiao, J.; Zhou, W.; Yang, Y.; Ren, X. Improving the strength and ductility of laser directed energy deposited CrMnFeCoNi high-entropy alloy by laser shock peening. Addit. Manuf. 2020, 35, 101417. [CrossRef]

148. Yao, H.; Tan, Z.; He, D.; Zhou, Z.; Zhou, Z.; Xue, Y.; Cui, L.; Chen, L.; Wang, G.; Yang, Y. High strength and ductility AlCrFeNiV high entropy alloy with hierarchically heterogeneous microstructure prepared by selective laser melting. J. Alloys Compd. 2020, 813, 152196. [CrossRef]

149. Vogiatzief, D.; Evirgen, A.; Gein, S.; Molina, V.R.; Weisheit, A.; Pedersen, M. Laser Powder Bed Fusion and Heat Treatment of an AlCrFe2Ni2 High Entropy Alloy. Front. Mater. 2020, 7. [CrossRef]

150. Lin, D.; Xu, L.; Jing, H.; Han, Y.; Zhao, L.; Minami, F. Effects of annealing on the structure and mechanical properties of FeCoCrNi high-entropy alloy fabricated via selective laser melting. Addit. Manuf. 2020, 32, 101058. [CrossRef]

151. Wang, R.; Zhang, K.; Davies, C.; Wu, X. Evolution of microstructure, mechanical and corrosion properties of AlCoCrFeNi high-entropy alloy prepared by direct laser fabrication. J. Alloys Compd. 2017, 694, 971-981. [CrossRef]

152. Moorehead, M.; Bertsch, K.; Niezgoda, M.; Parkin, C.; Elbakhshwan, M.; Sridharan, K.; Zhang, C.; Thoma, D.; Couet, A. High-throughput synthesis of Mo-Nb-Ta-W high-entropy alloys via additive manufacturing. Mater. Des. 2020, $187,108358$. [CrossRef]

153. Popov, V.V.; Katz-Demyanetz, A.; Koptyug, A.; Bamberger, M. Selective electron beam melting of $\mathrm{Al}_{0.5} \mathrm{CrMoNbTa}_{0.5}$ high entropy alloys using elemental powder blend. Heliyon 2019, 5, e01188. [CrossRef]

154. Welk, B.A.; Williams, R.E.A.; Viswanathan, G.B.; Gibson, M.A.; Liaw, P.K.; Fraser, H.L. Nature of the interfaces between the constituent phases in the high entropy alloy CoCrCuFeNiAl. Ultramicroscopy 2013, 134, 193-199. [CrossRef]

155. Yue, T.; Xie, H.; Lin, X.; Yang, H.; Meng, G. Solidification behaviour in laser cladding of AlCoCrCuFeNi high-entropy alloy on magnesium substrates. J. Alloys Compd. 2014, 587, 588-593. [CrossRef]

156. Vikram, R.J.; Murty, B.S.; Fabijanic, D.; Suwas, S. Insights into micro-mechanical response and texture of the additively manufactured eutectic high entropy alloy AlCoCrFeNi2.1. J. Alloys Compd. 2020, 827, 154034. [CrossRef]

157. Thapliyal, S.; Nene, S.S.; Agrawal, P.; Wang, T.; Morphew, C.; Mishra, R.S.; McWilliams, B.A.; Cho, K.C. Damage-tolerant, corrosion-resistant high entropy alloy with high strength and ductility by laser powder bed fusion additive manufacturing. Addit. Manuf. 2020, 36, 101455. [CrossRef]

158. Kenel, C.; Casati, N.P.M.; Dunand, D.C. 3D ink-extrusion additive manufacturing of CoCrFeNi high-entropy alloy micro-lattices. Nat. Commun. 2019, 10, 904. [CrossRef] [PubMed]

159. Kunce, I.; Polanski, M.; Bystrzycki, J. Structure and hydrogen storage properties of a high entropy ZrTiVCrFeNi alloy synthesized using Laser Engineered Net Shaping (LENS). Int. J. Hydrogen Energy 2013, 38, 12180-12189. [CrossRef]

160. Zhang, H.; Pan, Y.; He, Y.; Jiao, H. Microstructure and properties of 6FeNiCoSiCrAlTi high-entropy alloy coating prepared by laser cladding. Appl. Surf. Sci. 2011, 257, 2259-2263. [CrossRef]

161. Zheng, B.; Liu, Q.B.; Zhang, L.Y. Microstructure and Properties of MoFeCrTiW High-Entropy Alloy Coating Prepared by Laser Cladding. Adv. Mater. Res. 2013, 820, 63-66. [CrossRef]

162. Kunce, I.; Polanski, M.; Bystrzycki, J. Microstructure and hydrogen storage properties of a TiZrNbMoV high entropy alloy synthesized using Laser Engineered Net Shaping (LENS). Int. J. Hydrogen Energy 2014, 39, 9904-9910. [CrossRef]

163. Ni, C.; Shi, Y.; Liu, J.; Huang, G. Characterization of Al0.5FeCu0.7NiCoCr high-entropy alloy coating on aluminum alloy by laser cladding. Opt. Laser Technol. 2018, 105, 257-263. [CrossRef]

164. Dobbelstein, H.; Gurevich, E.L.; George, E.P.; Ostendorf, A.; Laplanche, G. Laser metal deposition of a refractory TiZrNbHfTa high-entropy alloy. Addit. Manuf. 2018, 24, 386-390. [CrossRef]

165. Katz-Demyanetz, A.; Gorbachev, I.I.; Eshed, E.; Popov, V.V.; Popov, V.V.; Bamberger, M. High entropy $\mathrm{Al}_{0.5} \mathrm{CrMoNbTa}_{0.5}$ alloy: Additive manufacturing vs. casting vs. CALPHAD approval calculations. Mater. Charact. 2020, 167, 110505. [CrossRef] 
166. Yang, X.; Zhou, Y.; Xi, S.; Chen, Z.; Wei, P.; He, C.; Li, T.; Gao, Y.; Wu, H. Additively manufactured fine grained Ni6Cr4WFe9Ti high entropy alloys with high strength and ductility. Mater. Sci. Eng. A 2019, 767, 138394. [CrossRef]

167. Zhou, R.; Liu, Y.; Liu, B.; Li, J.; Fang, Q. Precipitation behavior of selective laser melted FeCoCrNiC 0.05 high entropy alloy. Intermetallics 2019, 106, 20-25. [CrossRef]

168. He, J.; Wang, H.; Huang, H.; Xu, X.; Chen, M.; Wu, Y.; Liu, X.; Nieh, T.; An, K.; Lu, Z. A precipitation-hardened high-entropy alloy with outstanding tensile properties. Acta Mater. 2016, 102, 187-196. [CrossRef]

169. Wang, D.; Liu, L.; Huang, W.; Zhuang, H.L. Semiconducting SiGeSn high-entropy alloy: A density functional theory study. J. Appl. Phys. 2019, 126, 225703. [CrossRef]

170. Varvenne, C.; Curtin, W.A. Strengthening of high entropy alloys by dilute solute additions: CoCrFeNiAlx and CoCrFeNiMnAlx alloys. Scr. Mater. 2017, 138, 92-95. [CrossRef]

171. Oh, H.S.; Ma, D.; Leyson, G.P.; Grabowski, B.; Park, E.S.; Körmann, F.; Raabe, D. Lattice distortions in the FeCoNiCrMn high entropy alloy studied by theory and experiment. Entropy 2016, 18, 321. [CrossRef]

172. Sistla, H.R.; Newkirk, J.W.; Liou, F.F. Effect of Al/Ni ratio, heat treatment on phase transformations and microstructure of AlxFeCoCrNi2- x (x=0.3,1) high entropy alloys. Mater. Des. 2015, 81, 113-121. [CrossRef]

173. Toda-Caraballo, I.; Rivera-Díaz-del-Castillo, P.E. Modelling solid solution hardening in high entropy alloys. Acta Mater. 2015, 85, 14-23. [CrossRef]

174. Guo, Z.; Sha, W. Quantification of precipitation hardening and evolution of precipitates. Mater. Trans. 2002, 43, 1273-1282. [CrossRef]

175. Liu, Y.; Chen, Y.; Yu, K.; Wang, H.; Chen, J.; Zhang, X. Stacking fault and partial dislocation dominated strengthening mechanisms in highly textured Cu/Co multilayers. Int. J. Plast. 2013, 49, 152-163. [CrossRef]

176. Holzer, I.; Kozeschnik, E. Computer simulation of the yield strength evolution in Cu-precipitation strengthened ferritic steel. Mater. Sci. Eng. A 2010, 527, 3546-3551. [CrossRef]

177. He, F.; Chen, D.; Han, B.; Wu, Q.; Wang, Z.; Wei, S.; Wei, D.; Wang, J.; Liu, C.; Kai, J.-j. Design of D022 superlattice with superior strengthening effect in high entropy alloys. Acta Mater. 2019, 167, 275-286. [CrossRef]

178. Zhang, Y.; Wang, X.; Li, J.; Huang, Y.; Lu, Y.; Sun, X. Deformation mechanism during high-temperature tensile test in an eutectic high-entropy alloy AlCoCrFeNi2. 1. Mater. Sci. Eng. A 2018, 724, 148-155. [CrossRef]

179. Gladman, T. Precipitation hardening in metals. Mater. Sci. Technol. 1999, 15, 30-36. [CrossRef]

180. Zhang, L.; Zhou, Y.; Jin, X.; Du, X.; Li, B. Precipitation-hardened high entropy alloys with excellent tensile properties. Mater. Sci. Eng. A 2018, 732, 186-191. [CrossRef]

181. Zhao, Y.; Yang, T.; Tong, Y.; Wang, J.; Luan, J.; Jiao, Z.; Chen, D.; Yang, Y.; Hu, A.; Liu, C. Heterogeneous precipitation behavior and stacking-fault-mediated deformation in a CoCrNi-based medium-entropy alloy. Acta Mater. 2017, 138, 72-82. [CrossRef]

182. Eriş, R.; Akdeniz, M.V.; Mekhrabov, A.O. Atomic size effect of alloying elements on the formation, evolution and strengthening of $\gamma^{\prime}$-Ni3Al precipitates in Ni-based superalloys. Intermetallics 2019, 109, 37-47. [CrossRef]

183. Oblak, J.; Duvall, D.; Paulonis, D. An estimate of the strengthening arising from coherent, tetragonally-distorted particles. Mater. Sci. Eng. 1974, 13, 51-56. [CrossRef]

184. Eißmann, N.; Mühle, U.; Gaitzsch, U.; Walther, G.; Weißgärber, T.; Kieback, B. Precipitation hardening of high entropy alloy CoCrFeMnNi containing titanium. J. Alloys Compd. 2020, 857, 157610. [CrossRef]

185. Zhao, M.-C.; Yin, F.; Hanamura, T.; Nagai, K.; Atrens, A. Relationship between yield strength and grain size for a bimodal structural ultrafine-grained ferrite/cementite steel. Scr. Mater. 2007, 57, 857-860. [CrossRef]

186. Naik, S.N.; Walley, S.M. The Hall-Petch and inverse Hall-Petch relations and the hardness of nanocrystalline metals. J. Mater. Sci. 2020, 55, 2661-2681. [CrossRef]

187. Liu, W.; Wu, Y.; He, J.; Nieh, T.; Lu, Z. Grain growth and the Hall-Petch relationship in a high-entropy FeCrNiCoMn alloy. Scr. Mater. 2013, 68, 526-529. [CrossRef]

188. Liu, B.; Wang, J.; Liu, Y.; Fang, Q.; Wu, Y.; Chen, S.; Liu, C.T. Microstructure and mechanical properties of equimolar FeCoCrNi high entropy alloy prepared via powder extrusion. Intermetallics 2016, 75, 25-30. [CrossRef]

189. Ganji, R.S.; Karthik, P.S.; Rao, K.B.S.; Rajulapati, K.V. Strengthening mechanisms in equiatomic ultrafine grained $\mathrm{AlCoCrCuFeNi}$ high-entropy alloy studied by micro-and nanoindentation methods. Acta Mater. 2017, 125, 58-68. [CrossRef]

190. Courtney, T.H. Mechanical Behavior of Materials; Waveland Press: Long Grove, IL, USA, 2005.

191. Zhang, H.; He, Y.; Pan, Y. Enhanced hardness and fracture toughness of the laser-solidified FeCoNiCrCuTiMoAlSiB0.5 highentropy alloy by martensite strengthening. Scr. Mater. 2013, 69, 342-345. [CrossRef]

192. Ji, W.; Wang, W.; Wang, H.; Zhang, J.; Wang, Y.; Zhang, F.; Fu, Z. Alloying behavior and novel properties of CoCrFeNiMn high-entropy alloy fabricated by mechanical alloying and spark plasma sintering. Intermetallics 2015, 56, 24-27. [CrossRef]

193. Wu, Y.D.; Cai, Y.H.; Chen, X.H.; Wang, T.; Si, J.J.; Wang, L.; Wang, Y.D.; Hui, X.D. Phase composition and solid solution strengthening effect in TiZrNbMoV high-entropy alloys. Mater. Des. 2015, 83, 651-660. [CrossRef]

194. Otto, F.; Dlouhý, A.; Somsen, C.; Bei, H.; Eggeler, G.; George, E.P. The influences of temperature and microstructure on the tensile properties of a CoCrFeMnNi high-entropy alloy. Acta Mater. 2013, 61, 5743-5755. [CrossRef]

195. Liu, W.H.; Lu, Z.P.; He, J.Y.; Luan, J.H.; Wang, Z.J.; Liu, B.; Liu, Y.; Chen, M.W.; Liu, C.T. Ductile CoCrFeNiMox high entropy alloys strengthened by hard intermetallic phases. Acta Mater. 2016, 116, 332-342. [CrossRef] 
196. Liu, X.; Cheng, H.; Li, Z.; Wang, H.; Chang, F.; Wang, W.; Tang, Q.; Dai, P. Microstructure and mechanical properties of FeCoCrNiMnTi0.1C0.1 high-entropy alloy produced by mechanical alloying and vacuum hot pressing sintering. Vacuum 2019, 165, 297-304. [CrossRef]

197. Fu, Z.; Chen, W.; Wen, H.; Zhang, D.; Chen, Z.; Zheng, B.; Zhou, Y.; Lavernia, E.J. Microstructure and strengthening mechanisms in an FCC structured single-phase nanocrystalline Co25Ni25Fe25Al7.5Cu17.5 high-entropy alloy. Acta Mater. 2016, $107,59-71$. [CrossRef]

198. Li, Z.; Ludwig, A.; Savan, A.; Springer, H.; Raabe, D. Combinatorial metallurgical synthesis and processing of high-entropy alloys. J. Mater. Res. 2018, 33, 3156-3169. [CrossRef]

199. Borkar, T.; Chaudhary, V.; Gwalani, B.; Choudhuri, D.; Mikler, C.V.; Soni, V.; Alam, T.; Ramanujan, R.V.; Banerjee, R. A combinatorial approach for assessing the magnetic properties of high entropy alloys: Role of $\mathrm{Cr}$ in AlCoxCr1-xFeNi. Adv. Eng. Mater. 2017, 19, 1700048. [CrossRef]

200. Welk, B.A.; Gibson, M.A.; Fraser, H.L. A combinatorial approach to the investigation of metal systems that form both bulk metallic glasses and high entropy alloys. JOM 2016, 68, 1021-1026. [CrossRef] 